\title{
Seaweeds' nutraceutical and biomedical potential in cancer therapy: a concise review
}

\author{
João Cotas ${ }^{1}$, Diana Pacheco', Ana M. M. Gonçalves ${ }^{1,2}$, Paulo Silva ${ }^{3}$, Loïc G. Carvalho ${ }^{4,5}$, Leonel Pereira ${ }^{1}$ \\ 'University of Coimbra, MARE - Marine and Environmental Sciences Centre, Department of Life Sciences, Calçada Martim de \\ Freitas, Coimbra 3000-456, Portugal. \\ ${ }^{2}$ Department of Biology and CESAM, University of Aveiro, Aveiro 3810-193, Portugal. \\ ${ }^{3}$ UCIBIO-REQUIMTE, Departamento de Química, Faculdade de Ciências e Tecnologia, Universidade Nova de Lisboa, Caparica \\ 2829-516, Portugal. \\ ${ }^{4}$ The James Hutton Institute, Dundee DD2 5DA, Scotland, UK. \\ ${ }^{5}$ Heriot-Watt University, Edinburgh EH14 4AS, Scotland, UK.
}

Correspondence to: Prof./Dr. Leonel Pereira, Department of Life Sciences, University of Coimbra, MARE-Marine and Environmental Sciences Centre, Calçada Martim de Freitas, Coimbra 3000-456, Portugal. E-mail: leonel.pereira@uc.pt

How to cite this article: Cotas J, Pacheco D, Gonçalves AMM, Silva P, Carvalho LG, Pereira L. Seaweeds' nutraceutical and biomedical potential in cancer therapy: a concise review. J Cancer Metastasis Treat 2021;7:13.

http://dx.doi.org/10.20517/2394-4722.2020.134

Received: 30 Nov 2020 First Decision: 1 Feb 2021 Revised: 6 Feb 2021 Accepted: 19 Feb 2021 Published: 9 Mar 2021

Academic Editor: Stephen J. Ralph Copy Editor: Yue-Yue Zhang Production Editor: Yue-Yue Zhang

\begin{abstract}
Seaweeds have been a food source since ancient times (600 BC) and are still widely used in Asia, mainly in traditional Chinese medicine and Japanese folk medicine. Nowadays, seaweed compounds and extracts have been gaining interest from the biomedical and pharmaceutical market sectors. Seaweeds have been referenced as feasible solutions in finding new potential compounds and therapies in prevention, control, and reduction of cancer development due to the multirole of some bioactive components (e.g, phenolic compounds and sulphated polysaccharides). Moreover, seaweeds are rich in important health-promoting molecules [such as poly and highly unsaturated fatty acids (PUFAs and HUFAs), essential amino acids, vitamins, and dietary fibers] and minerals (calcium, iron, iodine, magnesium, phosphorus, potassium, zinc, copper, manganese, selenium, and fluoride). In this review, the potential therapeutic effects of seaweed in the prevention and treatment of cancer are approached, as well as nutraceutical properties of seaweed to promote cell homeostasis.
\end{abstract}

Keywords: Seaweed compounds, nutraceutical, bioactive molecules, cancer prevention, cancer treatment 


\section{INTRODUCTION}

Currently, the world's population is growing and getting older. Cancer is considered one of the major causes of death in the world ${ }^{[1]}$. There are multiple types of cancer which are differentiated on the origin of the responsible cell. This disease begins with a cell that is not functioning normally and then starts to grow and multiply uncontrollably, invading, conquering space, and interfering with other tissues, but also spreading through whole human organs depending on the type of abnormality that the cancer cell has ${ }^{[2]}$. This way, cancer can be classified as carcinoma, sarcoma, lymphoma and leukemia, germ cell tumor, or blastoma ${ }^{[3,4]}$. During the year 2018, it was estimated 18.1 million new cases of cancer were diagnosed and 9.6 million cancer deaths occurred $^{[5]}$, making it one of the main causes for human morbidity and mortality. Among the different types of cancer, breast, lung, and the colorectal cancers make up most of the cancer incidence worldwide ${ }^{[5-8]}$.

To ameliorate cancer incidence in human population, there is a need to develop new prevention and treatments/therapeutic schemes to avoid the appearance of malfunctioning cells (cancer prevention) and reduce cancer mortality through new biomedical tools for safer and cost-effective treatments ${ }^{[4]}$.

Over the past few years, there has been an increase of the associated search for new foods or dietary supplements that can help prevent the occurrence of cancer $^{[6]}$. For instance, it was observed that some diet strategies, mainly a western diet and respective lifestyle, are positively related to the growing cancer incidence ${ }^{[9,10]}$.

The options to treat cancer are surgical management, chemotherapy, radiotherapy, cancer-targeted therapy, and/or immunization therapy. Chemotherapy is the principal therapeutic method employed to treat cancer ${ }^{[11]}$. Moreover, there is also an enhanced search for new natural compounds that can be used as anti-cancer therapeutics, such as anti-cancer directed activity (through interference in cancer cell lines metabolic pathways), as drug delivery ingredient, or as chemo or radio-protective agent ${ }^{[4]}$.

The search for new tools to reduce cancer incidence and to efficiently destroy cancer cells with non-invasive techniques at a reasonable price has increased ${ }^{[4]}$. This has been achieved through focusing attention towards natural compounds from marine organisms, which can be an interesting source of compounds and have been used in East Asia for a long time (where cancer health problems seem reduced when compared with Western countries ${ }^{[12]}$.

One of the main ingredients used in East Asian food are seaweeds (also known as macroalgae), which are macroscopic (in most part of their lifetime), multicellular, photoautotrophic organisms. They mainly inhabit the seas or brackish water environments. Unlike terrestrial plants, they do not have vascular differentiations, seaweeds are distinguished by the coloration presented in thallus, by red (Rhodophyta), green (Chlorophyta), and brown (Phaeophyceae). Therefore, seaweeds live in multifaceted and dynamic aquatic ecosystems, due to a wide range of variations of biotic and abiotic factors during a day and between seasons ${ }^{[13-16]}$.

This way, seaweeds need to be able to adapt for survival in a constantly shifting ecosystem while also being a target as a primary food source. The main factors influencing seaweeds are hydration, temperature, salinity, light, pollutants, nutrients availability, and grazing ${ }^{[16-18]}$. The gathering of ecological data by the study of seaweed reactions to mentioned factors is important for biotechnological exploitation of seaweeds as depending on their acclimatization to the surrounding environment, they will produce a specific metabolic response ${ }^{[19-22]}$. Seaweeds are rich in health promoting molecules and minerals, such as sulphated polysaccharides, polyphenolics, terpenoids, flavonoids, pigments, MUFAs (monounsaturated fatty acids), PUFAs (polyunsaturated fatty acids), and HUFAs (highly unsaturated fatty acids), essential amino acids, 


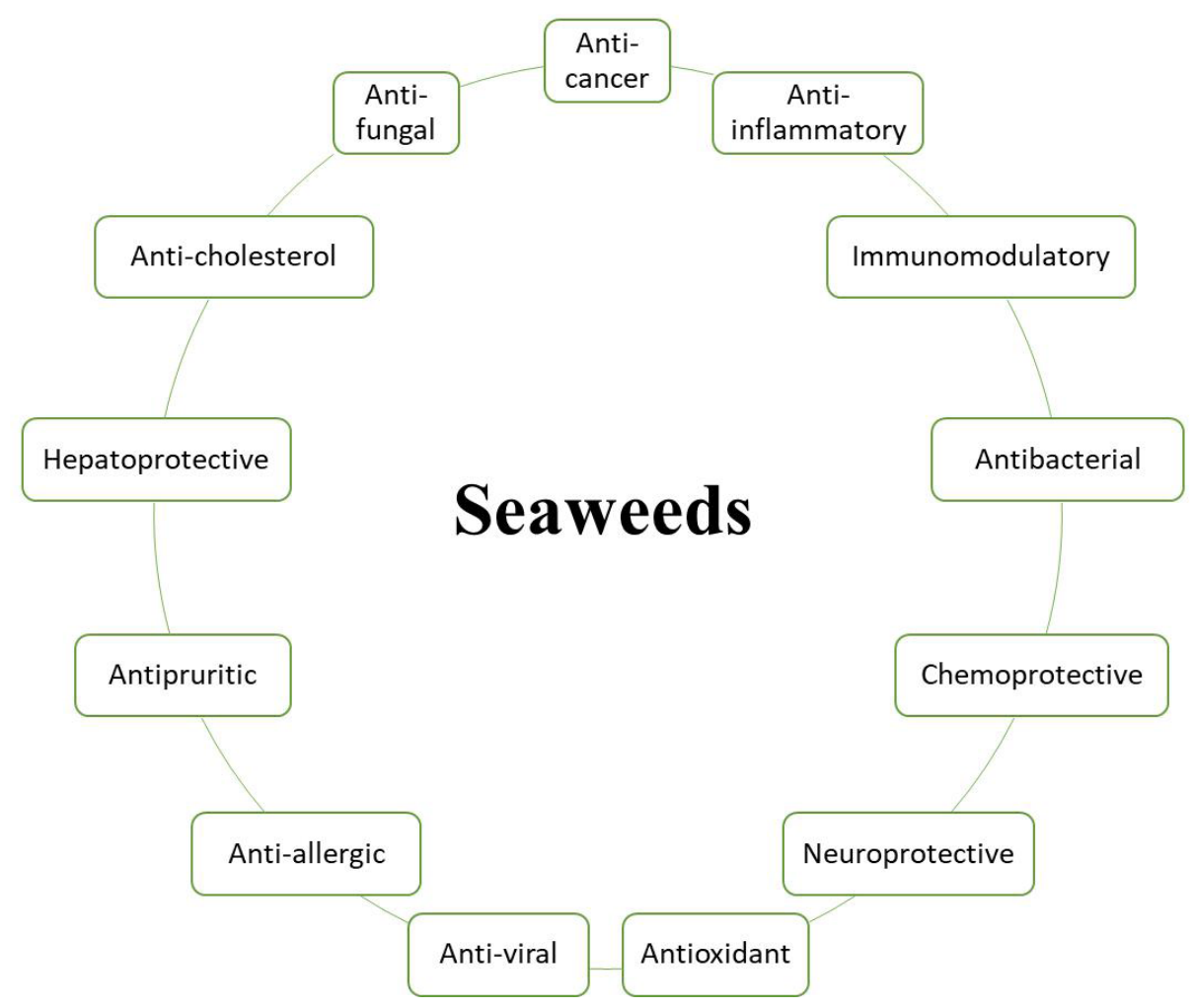

Figure 1. Seaweed compounds recorded biotechnological applications. However, they are not considered pharmaceutical products, only safe food with potential health benefits if consumed in quality and not quantity, and through a daily intake, as a supplement ${ }^{[32]}$. This has only been reported to be true when seaweeds are known to be certified by their quality and safety. Without it, seaweed consumption can have a negative impact due to possibility of toxins and metals accumulation, such as dioxins and heavy metals ${ }^{[35]}$.

vitamins $\left(A, B_{1}, B_{2}, B_{9}, B_{12}, C, D, E\right.$, and $\left.\mathrm{K}\right)$, and essential minerals (calcium, iron, iodine, magnesium, phosphorus, potassium, zinc, copper, manganese, selenium, and fluoride $)^{[23-25]}$. All these are known to be essential for the regular organism functioning ${ }^{[18,26-31]}$.

Seaweeds have interesting compounds for the development of novel food products and of nutraceuticals [Figure 1]. A nutraceutical product is a food that has positive effects on human health beyond its nutritional value, thus it might help prevent health problems, such as cancer, arthritis, diabetes, autoimmune diseases, ocular diseases, and cardiovascular diseases ${ }^{[32-35]}$. These benefits result from the many bioactivities seaweeds and their extracted compounds can possess: anti-cancer, anti-fungal, anti-inflammatory, anti-cholesterol, anti-pruritic, anti-allergic, anti-viral, anti-bacterial, antioxidant, neuroprotective, chemoprotective, immunomodulatory, and hepatoprotective [Figure 1].

However, seaweed potential application in cancer treatment is not strictly preventive. There are studies that already support the biomedical potential of isolated compounds when applied in various cancer therapeutic solutions, such as anti-cancer compounds (by inhibition of cancer cell growth and invasion, but also antimutagenic, anti-metastatic, and apoptosis induction potential), drug delivery system, and chemoprotective agent [Figure 2] $]^{[34,36-42]}$.

In this review, the main subjects addressed are seaweeds' role in cancer development prevention and the potential of seaweed compounds in cancer treatment from a therapeutic and nutraceutical point of view. 


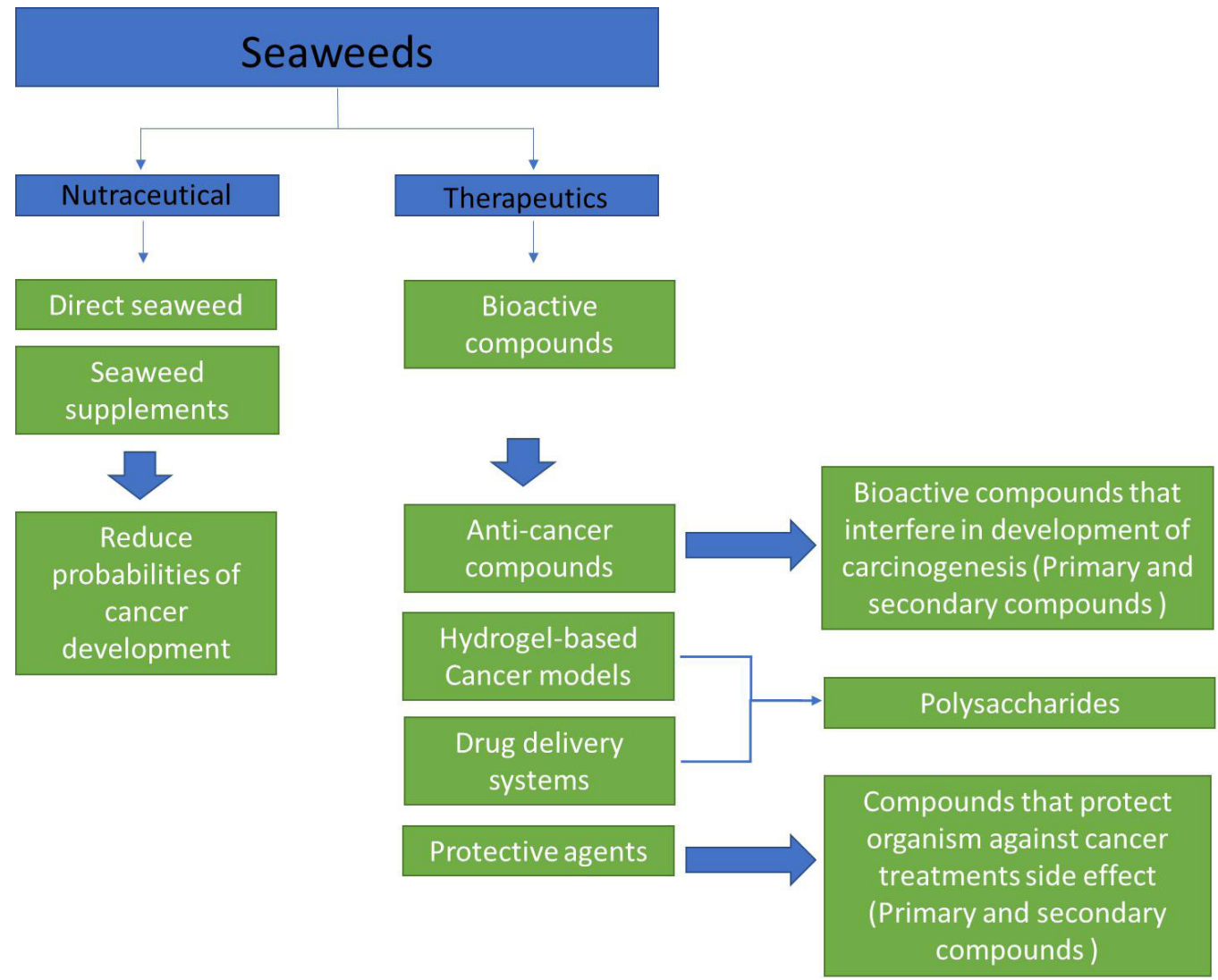

Figure 2. Seaweeds' main nutraceutical and therapeutic applications in cancer treatment research.

Data was collected from online databases, mainly Web of Science, Google Scholar, and PubMed, considering research articles, books, chapters, and reviews. The selected topics included the following combinations: seaweed, macroalgae, cancer, tumor, carcinogenesis.

After critical analysis of this thematic, the review focused on the seaweed nutraceutical potential and existing studies prospecting seaweed consumption as a food supplement and its potential correlation with cancer incidence. Moreover, the review also analyzes the potential of seaweed compounds in cancer treatment and the road that these need to go through before clinical application. The review does not focus on pre-clinical studies nor compounds screening, as there are already recent reviews which are excellent compendiums of the seaweed compounds with anti-cancer activity against various types of cancer cells $\mathrm{s}^{[4,34,41,43-45]}$.

\section{SEAWEEDS AS CELL HOMEOTASIS PROMOTERS}

The incorporation of seaweed in the basis of a daily diet has been adopted by ancient civilizations in the East Asian countries ${ }^{[46,47]}$. Moreover, several coastal countries worldwide have records of seaweed consumption ${ }^{[48,49]}$. Despite the recent global trend regarding the introduction of seaweed as a health promoter supplement, these sea vegetables have been used for a long time by Asian populations as a flavor enhancer agent in food products, drinks, and beverages ${ }^{[47,50,51]}$.

Despite the reluctance by some cultures to integrate seaweed in their daily diet due to metal bioaccumulation ability from macroalgae, studies showed that the trace element content of highly consumed species does not exceed the values referenced as safe for consumption, according to European Food Safety Authority (EFSA) threshold, as reviewed by other authors ${ }^{[52]}$. 
Among the several benefits of seaweed incorporation in human daily diet, researchers demonstrated that their consumption is directly related with lower probabilities of cancer development ${ }^{[47]}$. For instance, researchers found evidences that, among the East Asian population, people with a regular seaweed consumption habit reduced the risk of colorectal cancer development by half $f^{[35]}$. On the other hand, people with a meat and processed food based diet and occasional seaweed consumption, had higher risk of developing this type of cancer $^{[53,54]}$.

In fact, in Western countries, higher cancer incidence was recorded when compared to Japan ${ }^{[5,8,55,56]}$. With the increase of food availability and processed food commerce throughout developed countries, a general adoption towards fast meals is being observed. For instance, among the Japanese population, increased consumption of red meat and dairy products concurred with a period of higher incidence of chronic diseases $^{[57,58]}$.

To corroborate this hypothesis, researchers have been highlighting seaweeds' anti-cancer bioactivities through in vitro and in vivo experiments, while also observing and reporting that regular seaweed intake has been directly related to lower mortality rates among patients diagnosed with lung or pancreatic cancers $^{[59]}$.

On the other hand, there is a need to certify the seaweed quality before commercialization due to potential problems of high heavy metals and iodine concentrations ${ }^{[47]}$. To surpass this issue, there is a need to develop legislation to support seaweeds safe consumption; for example, the FDA (USA) and EFSA (EU) are active entities in assuring seaweed minimum quality for the food market ${ }^{[35,60]}$.

\section{Seaweed compounds profiles: nutraceutical effects}

Seaweeds are in fact a food product that can provide essential macro and micronutrients, as well as trace elements, which are pivotal to maintain human cell homeostasis. However, it is necessary to consider that seaweed biochemical profiles differ according to species, geographical location, tidal exposure, season, physico-chemical composition of the water, or even with the seaweed processing techniques ${ }^{[17,61-63]}$. Nevertheless, they are considered a nutraceutical and valuable resource due to their richness in proteins, minerals, vitamins, polysaccharides, pigments, and phenols ${ }^{[64-66]}$.

Diseases such as diabetes, obesity or cardiovascular problems are often associated with a high fat diet ${ }^{[6,67,68]}$. Particularly, the increase of total cholesterol and low-density lipoprotein cholesterol (LDL-C) are the main risk factors that promote the development of cardiovascular diseases ${ }^{[69]}$. Studies highlight the importance of including food products rich in polyunsaturated fatty acids in our diets on a daily basis to boost the immune system ${ }^{[70]}$. Furthermore, lipids are essential macronutrients to the proper performance of the human body. These compounds integrate several metabolic pathways, such as energy supply, hormones and membranes synthesis ${ }^{[71]}$. These compounds are also important for vitamins transport and absorption ${ }^{[6,68]}$. In this context, seaweeds are a well-known source of essential fatty acids, which the human body is not able to synthesize, such as omega-3 (n-3) and omega-6 (n-6) ${ }^{[72,73]}$.

A diet poor in proteins can lead to the development of several diseases, such as hyperphagia or thermogenesis, which are associated with obesity ${ }^{[74-76]}$. Therefore, it is important to have a varied diet with significant protein uptake. Seaweeds can synthesize all the essential amino acids, which the human body is not able to produce and needs to take from the diet, namely histidine, isoleucine, leucine, lysine, methionine, phenylalanine, threonine, tryptophan, and valine ${ }^{[63,77-79]}$.

Proteins are extremely important molecules for the good function of the human body. These macromolecules are key elements in skin, bones, muscles, and cartilage regenerations as enzymes, hormones, or antibodies precursors ${ }^{[62,77]}$. 
Seaweed polysaccharides are a promising dietary supplement due to their chemical and structural characteristics. Since the human body does not possess enzymes capable of degrading some of these long-chain polymers (polysaccharides weighing over $120 \mathrm{kDa}$ ), they are considered healthy sugars that satiate, but are not absorbed ${ }^{[80]}$. In this context, seaweed polysaccharides such as agar, carrageenan, and alginate are health promoters, preventing diseases related with obesity ${ }^{[81,82]}$. Moreover, researchers already demonstrated that commercially available products containing carrageenan can be an anti-cholesterol agent ${ }^{[83]}$. Several studies also highlight pharmacological bioactivities of these natural compounds, such as antioxidant, neuroprotective, anti-bacterial, or anti-inflammatory ${ }^{[84-86]}$. Fucoidan and other low molecular polysaccharides can be absorbed in the gastrointestinal systems ${ }^{[87-91]}$. In fact, seaweed polysaccharides behave as dietary fibers known to stimulate intestinal mucus production and thickness, providing protection against toxins and carcinogenic compounds ${ }^{[92,93]}$.

Micronutrients, such as minerals (calcium, magnesium, phosphorous, or potassium), trace elements (manganese, iron, zinc, or iodine), and vitamins (A, D, E, and $\mathrm{K}$ ), even in low amounts, are crucial substances for the human body ${ }^{[94,95]}$. The lack of these compounds is responsible for several diseases, such as anemia, xerophthalmia, osteoporosis, and increases the risks of developing cancer and cardiovascular diseases ${ }^{[96,97]}$. These compounds are important structural elements of the skeleton and are also involved in regulatory functions of the human body, such as oxygen transport or neurotransmission ${ }^{[94]}$.

Undernourishment prevention is a complex challenge in which it is necessary to ensure a balanced and varied diet, rich in all key nutrients needed to the good functioning of the human body ${ }^{[96]}$. Seaweeds exhibit a rich nutritional content, being rich in several micronutrients, such as iodine, magnesium, sodium, and potassium ${ }^{[23,98]}$. Moreover, seaweeds are also a source of vitamins, namely A, B, C, and E, which are essential elements in a healthy diet ${ }^{[9-103]}$. Therefore, seaweeds can be useful natural and nutraceutical food resources that can contribute to a healthier diet and potentially help prevent cancer by contributing to better nutritional balance ${ }^{[5,53]}$.

Seaweeds are natural sources of pigments, such as phycocyanin, phycoerythrin, $\beta$-carotene, $\alpha$-carotene, fucoxanthin, astaxanthin, canthaxanthin, zeaxanthin, and lutein ${ }^{[104-106]}$. These compounds are known for their antioxidant bioactivity which is privileged on cancer prevention as free radicals are recognized as a sign of stress or imbalance, thus contributing to potential cancer development ${ }^{[107,108]}$. In fact, these compounds are already widely used in food and cosmetic industries as natural colorants ${ }^{[24,109-112]}$. However, they are also applied in medical assays as biomarkers ${ }^{[113,114]}$.

Many studies focus on the study of pigments' bioactivities, revealing interesting biomedical applications, such as chemotherapeutical and neuroprotective agents, tumor suppression activity, anti-inflammatory, and anti-irradiative effects ${ }^{[115-117]}$. For instance, phycobiliproteins have revealed their nutraceutical and pharmacological potential ${ }^{[12,115]}$ through their antioxidant ${ }^{[118]}$, anti-inflammatory ${ }^{[122]}$, antitumor ${ }^{[119]}$, antienterovirus $^{[120]}$, and hepatoprotective ${ }^{[121]}$ bioactivities. Moreover, investigation findings reported that carotenoids are highly valuable compounds with potential pharmaceutical application due to their antioxidant ${ }^{[105,106]}$, anti-inflammatory ${ }^{[106,122]}$, and anti-cancer ${ }^{[123]}$ bioactivities, reducing the risks of several diseases affecting humans ${ }^{[124-127]}$.

Phenolic compounds are secondary metabolites derived from seaweeds, likewise phlorotannins, bromophenols, flavonoids, phenolic terpenoids, and mycosporine-like amino acids, being considered bioactive molecules. These metabolic products are normally produced by seaweeds as response to environmental and ecological stress factors, such as herbivory and ultraviolet radiation exposure ${ }^{[128]}$. Research has showed that the mentioned compounds have wide biotechnological applications, such as anti-inflammatory, anti-bacterial, anti-viral, anti-allergic, anti-diabetic, antioxidant, anti-photoaging, 
anti-pruritic, hepatoprotective, hypotension, neuroprotective, and anti-cancer properties ${ }^{[129-142]}$. These compounds can interact with cell receptors, enzymes, and proteins, enhance the immune system, and exhibit several biological activities that are important to maintaining good health ${ }^{[143]}$. All of the mentioned characteristics and properties of these compounds makes them suitable candidates for the development of novel pharmacological, cosmeceutical, and nutraceutical products ${ }^{[19,139,141,144,145]}$. For this reason, phenolic compounds can be employed as health agent promoting food supplements and even increase food products shelf-life ${ }^{[146,147]}$.

Furthermore, seaweed sterols, such as desmosterol, cholesta-4,6-dien-3-ol, and cholest-5-ene-3,7-diol ${ }^{[148-150]}$ are essential molecules for structural and hormonal function, with antioxidant, anti-viral, anti-fungal, and anti-bacterial bioactivities ${ }^{[33,34,126,151]}$.

\section{Seaweeds intake and cancer relationship: a nutraceutical effect?}

Several epidemiological records, in most of the cases around the world, have proposed that cancer is an avoidable disease. The causes of cancer development normally share pathogenic mechanisms such as DNA damage, oxidative stress, and/or chronic inflammation ${ }^{[47,152]}$. Currently, further studies aimed to understand cancer development and its prevention concluded that mitigation measures depend on better daily choices, such as avoiding excessive UV light and radiation exposure, reducing alcohol consumption, not smoking, and choosing healthy food diets [Figure $3 \mathrm{~A}]^{[153]}$.

As mentioned before, in some countries, mainly in East Asia, there is a tradition of seaweeds consumption, which, as previously referred, are rich in biological active metabolites and other macro and micronutrients that regulate the good function of the human body in a recommended daily intake ${ }^{[153]}$. An example are brown seaweeds, which are a very popular food in Japan. It was demonstrated that $5 \mathrm{~g}$ per day of dried seaweed is well tolerated in the human organism, and in a traditional Japanese diet, the average daily seaweed intake is normally around 4-7 $\mathrm{g}$ of dried seaweed ${ }^{[154]}$.

Minami et al. ${ }^{[155]}$ demonstrated that seaweed consumption decreased the patient mortality with colon and rectal cancer using cancer patients in Japan. This could be due to the seaweed polysaccharides, which in the human gastrointestinal system behave as dietary fibers. Seaweed polysaccharides can alter the microbiota structure in the human gastrointestinal tract ${ }^{[156-158]}$. A high fiber diet ingestion enhances the microbiota population to produce short-chain fatty acids, which have demonstrated to have anti-cancer and antiinflammatory effects ${ }^{[159-161]}$. This type of modulation of the gastrointestinal microbiota by dietary fibers could have a positive impact in the prevention of stomach cancer ${ }^{[162]}$. This type of benefit from seaweed intake also appears to be related with the consumption of Laminaria/ Saccharina sp., or other brown seaweeds (Undaria pinnatifida) that can help the gastrointestinal system and prevent the initiation of breast cancer or its development by endogenous human factors ${ }^{[163]}$. This can be due to the iodine content, among other compounds, in brown seaweeds ${ }^{[164,165]}$. Funahashi et al ${ }^{[166]}$ reported that consumption of U. pinnatifida [Figure 3B] demonstrates high suppressive effect against mammary cancer in an in vivo rat model, even at a low percentage (seaweed flakes, at $1 \%-5 \%$ dry weight as a supplement integrated in the feeding). However, these results are only from rat models and more detailed information is still needed regarding human trials ${ }^{[165]}$. Nevertheless, this assay with Laminaria/Saccharina sp. showed a chemo-preventive pattern against cancer incidence that might be promising in the future ${ }^{[166]}$. However, there is explicit risk that overdosage can have negative effects. Teas et al. ${ }^{[93]}$ reported that, among women from the USA, consuming $U$. pinnatifida revealed positive effects against breast cancer. The seaweed intake lowered urokinase-type plasminogen activator receptor ( $\mathrm{UPAR}$ ), an important receptor to the cell homeostasis, participating in various metabolic pathways which, when in high concentration, can increase abnormal cell function and develop into a cancer ${ }^{[93]}$. The observed seaweed intake from this study ( $5 \mathrm{~g}$ of encapsulated seaweed powder per day) lowered the level of the uPar up to $50 \%$ of the initial concentration in urine ${ }^{[68]}$. This supplement 


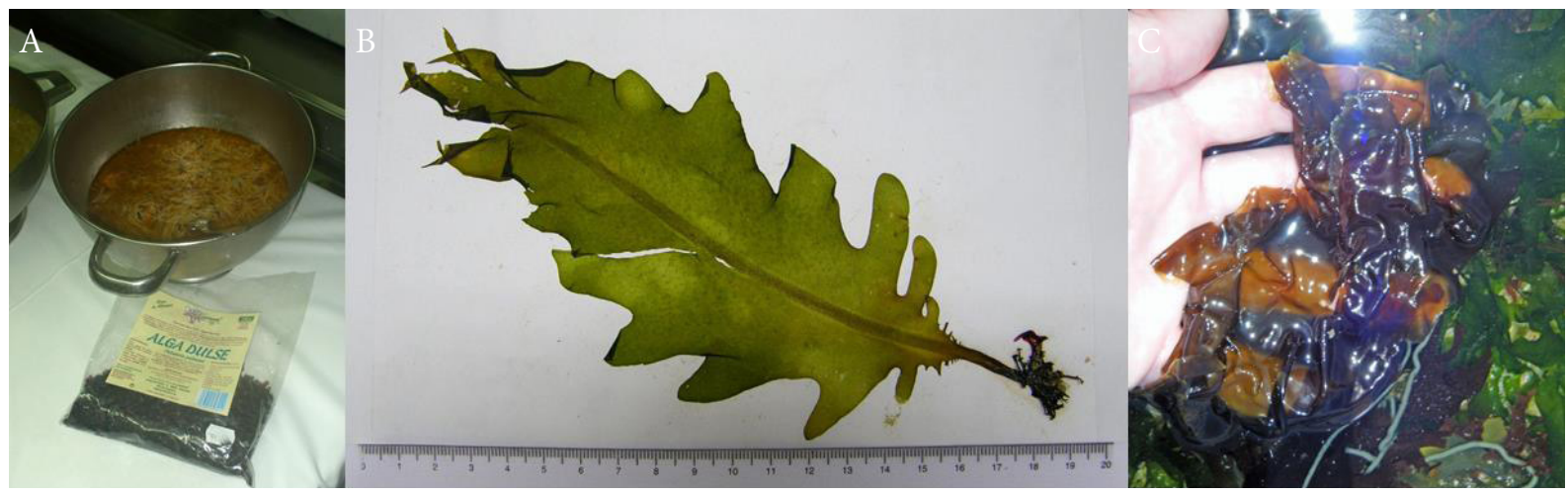

Figure 3. Examples of edible seaweed specimens. A: Seaweed soup with Palmaria palmata; B: Undaria pinnatifida herbarium specimen; C: Wild specimen of Porphyra umbilicalis in Cabo Mondego beach, Figueira da Foz, Coimbra, Portugal.

can be useful for women in the premenopausal period to reduce the potential development of breast cancer, mainly due to iodine concentration in brown seaweeds ${ }^{[154]}$. Also to be noted, $5 \mathrm{~g}$ of dried seaweed (Undaria sp., Laminaria sp., Saccharina sp., and Alaria sp.) have demonstrated to increase the thyroid stimulating hormone, yet, the increase was considered small and not biologically relevant ${ }^{[154]}$. Nevertheless, high concentration of iodine in seaweed is considered a risk towards development of thyroid cancer ${ }^{[47]}$. In this case, the dosage is the main factor of the benefit or problematic of seaweeds intake ${ }^{[47,167]}$. From another study in South Korea, Undaria pinnatifida intake among women (362, between 30-65 years old) did not correlate to a lower breast cancer incidence ${ }^{[168]}$. However, in the same study, the high intake of Porphyral Pyropia sp. decreased the risks of breast cancer [Figure $3 \mathrm{C}]^{[168]}$.

To consider seaweeds as nutraceutical ingredients, there is a need of more assays to fully understand their potential as preventive sources against cancer and other human diseases ${ }^{[169]}$. Even though more work is necessary, the reviewed results reported here can be considered a positive support towards classifying seaweeds as favorable nutraceuticals for humans against cancer incidence. In future work, to start understanding the true nature of this seaweed potential against cancer incidence, studies should start considering the nutritional profiles. Nutritional profile of the seaweed content used, as previously mentioned, can vary greatly among the same species depending on the conditions it grew or was harvested and processed ${ }^{[35,52,170]}$. This could bring some clarification in situations like the reported U. pinnatifida studies in USA and Korea, which reported opposite results.

\section{BIOMEDICAL POTENTIAL OF SEAWEED COMPOUNDS}

Seaweeds have high nutritional potential with nutraceutical potential, as previously demonstrated. However, seaweed isolated compounds have been studied and reveal a wide range of bioactive potential, such as anti-bacterial, anti-viral, anti-allergic, anti-diabetic, antioxidant, anti-photoaging, anti-pruritic, hepatoprotective, hypotension, neuroprotective, and anticancer properties ${ }^{[130,133,141]}$. Moreover, there are diverse pharmaceuticals and new drugs with seaweed compounds as active agents with the most known being phlorotannins to treat cardiovascular diseases ${ }^{[171]}$, or secondary compounds to encapsulate or stabilize the active agent, for example, the brown seaweed polymer alginate ${ }^{[172]}$. However, the most explored seaweed compounds in the biomedical area are phenolic compounds, pigments, and polysaccharides.

\section{Phenolic compounds}

Phenols are secondary metabolic products of seaweed, which are a complex category of chemical compounds that are water-soluble compounds and which share a hydroxyl group connected to an aromatic hydrocarbon group ${ }^{[171]}$. Phenols can be classified into basic phenolic compounds according to the number 
of substituents, comprising terpenoids, flavonoids, phlorotannins, bromophenols, and several mycosporinelike amino acids ${ }^{[171]}$.

These compounds have a wide range of bioactivities, such as anti-tumor, anti-diabetic (with commercial drugs already in use), antiviral, antioxidant, neuroprotection, anti-inflammatory, and sleep-promoting properties (to ameliorate the insomnia and other sleep disorders) ${ }^{[171]}$.

\section{Pigments}

Three kinds of pigments groups can be produced by seaweeds as photosynthetic organisms: chlorophylls, carotenoids, and phycobiliproteins. The color of the algae determines the pigments in them. The presence of chlorophylls a and b causes the green color. Phycobilins, such as phycoerythrin and phycocyanin, are responsible for the red color. Where the chlorophylls a, c1, and c2, b-carotene, and fucoxanthin are usually the pigments present in brown seaweeds ${ }^{[173]}$.

These isolated compounds have been documented with anti-bacterial, anti-inflammatory, neuroprotection antioxidant, and anti-tumor effects ${ }^{[170]}$. And, these compounds are being studied to be applied as fluorescent markers in the biomedical field ${ }^{[113]}$.

\section{Polysaccharides}

In the present biomedical field, seaweed-derived polysaccharides with specific structural and functional characteristics have acquired special research focus ${ }^{[174}$. Researchers and industry have been using the benefic inherited characteristics of seaweed polysaccharides, such as those of a biologically tunable, biocompatible, biodegradable, reusable, and non-toxic nature, to design new biomaterial for drug delivery, tissue engineering, and wound dressings ${ }^{[172,174]}$. Seaweed polysaccharide are therapeutically effective with controlled distribution ${ }^{[174]}$. Especially with alginate, an anionic polymer without high bioactivity and unlike other seaweed polysaccharides like fucoidan, which is an anionic sulfated polysaccharide extracted from brown seaweed, which possess a wide range of bioactivities: anti-inflammatory, anti-oxidative, anticoagulant, and antithrombotic effects ${ }^{[175]}$. Fucoidan has been widely researched over the past decade to be applied on drug and gene delivery systems and diagnostic microparticles ${ }^{[175]}$.

From red seaweed, carrageenan was used as a popular medicine from ancient times to ameliorate cough and common colds and this has been confirmed by in vitro and in vivo assays. This ability is primarily derived from the function of carrageenan to suppress blood platelet aggregation (i.e. anticoagulant activity) ${ }^{[6,176]}$. Different carrageenans excel in other demonstrable bioactivities such, anti-tumor, anti-viral, and immunomodulation activities, being commercially exploited due to their anti-viral properties ${ }^{[177,178]}$. Agar is applied in the biomedical field as a bulking and suspension component in drug solutions and in prescription products, but also as anti-coagulant agents and as a laxative in capsules and tablets. Moreover, they are also used for development of new biomedical techniques of analysis and characterization ${ }^{[178-180]}$.

\section{Other compounds with biomedical interest}

There are compounds isolated from seaweed which have a general lack of published studies ${ }^{[181]}$. Fatty acids can play an important role in the development of new biomedical solutions for immunomodulation drugs and in the treatment and prevention of many neoplastic, ocular, cardiovascular, neurodegenerative, and autoimmune disorders ${ }^{[170,181]}$. Seaweed sterols are precursors of plant and animal hormones and also have many bioactivities, such as antioxidants, antivirals, anti-fungal, and anti-bacterial ${ }^{[33]}$.

Although there is this seaweed biomedical potential, only a reduced number of seaweed compounds are already being applied in the biomedical field ${ }^{[3,44,171]}$. As the biomedical interest in seaweed is fairly recent, there is need for more research and development around other potential seaweed compounds for this field. 


\section{SEAWEEDS COMPOUNDS IN CANCER THERAPY/THERAPEUTICS: A POTENTIAL TO EXPLORE}

When cancer develops, there is a need to take immediate action to destroy or reduce its impact. Thus, a request in the search for new therapeutics is necessary as what is available does not seem to be successful enough. This is mainly due to available treatments being very harmful (with wide range of negative secondary effects) and actual efficiency of the most common techniques being low. Only some very expensive techniques seem to have low secondary effects with high efficiency in destroying cancer cells ${ }^{[18,182-184]}$. Recent research has been focusing efforts in the discovery of compounds which are costeffective, efficient and with low or absence of secondary effects ${ }^{[182]}$. In this case, there are several molecules derived from marine organisms proven to be beneficial in various stages against cancer proliferation and also against various different human cancer lines ${ }^{[182]}$. However, from discovery to final product, it is a long step with various clinical stages and, so far, seaweeds anti-cancer potential has only been evaluated through what can be considered pre-clinical stage studies (in vitro and in vivo assays). Nevertheless, there are already some components, mainly sulphated polysaccharides (fucoidan/laminarin), that are in clinical stage studies and with promising results which might end with new therapeutic agents in a few years ${ }^{[34,185]}$. In vivo assays are mainly based in rodent model systems and results might differ in humans. Therefore, there is the urge for new study models with improved assay methodologies for a better assessment of potential new therapies where new in vitro assays could be a solution along with tissue engineering ${ }^{[18]}$. Clinical trials with patients are risky due to the poor and life-threatening health status of cancer patients in which trials with experimenting components need to be critically analyzed due to the potential interaction with the cancer treatment already in course ${ }^{[6]}$. This is why experimental studies in course among Cancer Treatment Medical Facilities are toned to guarantee patient health status monitoring and can only use new therapeutics which passed the pre-clinical and safety assays ${ }^{[186,187]}$. For example, the Bis(2,3-dibromo4,5-dihydroxybenzyl) ether compound isolated and characterized in red seaweeds, is now chemically synthetized for further studies ${ }^{[188,189]}$. This compound has demonstrated anti-angiogenesis properties in vitro and in vivo (in zebrafish embryos), by decreasing the HUVEC (human umbilical vein endothelial cells) cells proliferation, migration, and also tube formation ${ }^{[188]}$. These assays, together with the fact that the compound itself displays a different chemical structure than other anti-angiogenesis therapeutic agents, support the potential for further studies towards cancer ${ }^{[188,190]}$.

\section{Bioactive compounds against cancer}

The development of cancer (carcinogenesis) is a multi-step process described by diverse marks, such as sustention of proliferative signaling, evasion of growth suppressors, resistance to cell death, activation of invasion and metastasis, and induction of angiogenesis ${ }^{[191]}$. The wide range of molecular targets and carcinogenesis mechanisms allows a further exploitation of natural anti-cancer agents efficient in one particular step of all core steps from carcinogenesis ${ }^{[192]}$. The main targets where anti-cancer therapeutics usually work could be: preventing cell resistance to apoptosis or cell cycle checkpoints modifications, directly protecting DNA from damage or enhancing DNA repair mechanisms, and/or protecting against oxidative stress and reactive oxygen species $(\mathrm{ROS})^{[93,193-196]}$. Natural compounds have gained interest due to the increase of cancer resistance and undesirable side effects among synthetic choices. Therefore, natural compounds could integrate cancer therapies, targeting one of the carcinogenesis pathways without cytotoxic effects to the healthy cells, and combined with other types of already applied synthetic drugs, reducing side effects and potentially enhancing the therapeutic outcome ${ }^{[192]}$. In this field, there are already very incisive reviews with high volume of screened potential anti-cancer seaweed compounds, such as phenols, sulphated polysaccharides, halogenated compounds, peptides, pigments, fatty acids, among other types of compounds, making them excellent bibliographic compendia of seaweed compounds assayed and tested in vitro and in vivo in role models against various cancer cells types [Table 1]. 
Table 1. Screened seaweed compounds for anti-cancer activity

\begin{tabular}{|c|c|c|c|c|c|c|c|}
\hline Source & Compound & Type of cancer & Model & Activity & Concentration & Possible pathway & Ref. \\
\hline Undaria pinnatifida & Fucoidan & $\begin{array}{l}\text { Hepatocellular } \\
\text { carcinoma }\end{array}$ & Hep G2 cells & Anti-cancer & $\mathrm{LD}_{50}$ of $18.01 \mu \mathrm{g} / \mathrm{mL}$ & $\begin{array}{l}\text { Oxidative stress and } \\
\text { chronic inflammation } \\
\text { reduction }\end{array}$ & $\begin{array}{l}{[197-} \\
199]\end{array}$ \\
\hline $\begin{array}{l}\text { Sigma Chemical } \\
\text { Company }\end{array}$ & Eckol & $\mathrm{Nd}^{*}$ & V79-4 cells & Radioprotective & $10 \mu \mathrm{g} / \mathrm{mL}$ & $\begin{array}{l}\text { Inhibition of cellular } \\
\text { DNA damage and } \\
\text { membrane lipid } \\
\text { peroxidation }\end{array}$ & [38] \\
\hline Eisenia bicyclis & $\begin{array}{l}\text { Phlorofucofuroeckol } \\
\text { A }\end{array}$ & $\begin{array}{l}\text { Colorectal } \\
\text { adenocarcinoma }\end{array}$ & $\begin{array}{l}\text { HCT 116, SW480, } \\
\text { LoVo and HT-29 } \\
\text { cell lines }\end{array}$ & Anti-proliferative & $\begin{array}{l}\text { Reduced cell viability } \\
\text { by } 16 \% \text { and } 42 \% \text { at } \\
50 \mu \mathrm{M} \text {, and } 38 \% \text { and } \\
90 \% \text { at } 100 \mu \mathrm{M} \text { in } \\
\mathrm{HCT} 116 \text { and SW } 480 \\
\text { cells, respectively } \\
\text { LoVo and } \\
\text { HT- } 29 \text { cells were } \\
\text { decreased by } 39 \% \\
\text { and } 25 \% \text { at } 50 \mu \mathrm{M} \text { of } \\
\text { PFF-A, and } 47 \% \text { and } \\
31 \% \text { at } 100 \mu \mathrm{M}\end{array}$ & $\begin{array}{l}\text { Activates the } \\
\text { transcription of factor } \\
3 \text { (ATF3) expression } \\
\text { by regulating } \\
\text { transcriptional activity } \\
\text { and apoptosis in } \\
\text { human colorectal } \\
\text { cancer cells }\end{array}$ & [200] \\
\hline $\begin{array}{l}\text { Carpodesmia } \\
\text { tamariscifolia (formerly } \\
\text { Cystoseira tamariscifolia) }\end{array}$ & Isololiolide & $\begin{array}{l}\text { Hepatocellular } \\
\text { carcinoma }\end{array}$ & $\begin{array}{l}\text { Hep G2, AGS and } \\
\text { HCT-15 cell lines }\end{array}$ & Anti-cancer & $\begin{array}{l}\mathrm{IC}_{50} \text { values } 13.15 \mu \mathrm{M} \\
32.36 \mu \mathrm{M} \text {, and } 23.59 \\
\mu \mathrm{M} \text {, respectively }\end{array}$ & $\begin{array}{l}\text { Caspase- } 3 \text { activation, } \\
\text { decreased } \mathrm{Bcl}-2 \\
\text { levels, increased p53 } \\
\text { expression and PARP } \\
\text { cleavage }\end{array}$ & [201] \\
\hline Brown seaweeds & Phloroglucinol & $\begin{array}{l}\text { Intraductal } \\
\text { carcinoma }\end{array}$ & MCF-7 cell line & Anti-cancer & $\mathrm{IC}_{50} 50 \mu \mathrm{M}$ & $\begin{array}{l}\text { Decreased CD } 44^{+} \\
\text {cancer cell population, } \\
\text { as well as expression } \\
\text { of CSC regulators such } \\
\text { as Sox } 2, \text { CD } 44 \text {, Oct4, } \\
\text { Notch2 and } \beta \text {-catenin; } \\
\text { Inhibited KRAS and } \\
\text { its downstream PI3K/ } \\
\text { AKT and RAF-1/ERK } \\
\text { signaling pathway }\end{array}$ & [202]. \\
\hline Sigma-Aldrich & $\begin{array}{l}\kappa \text {-carrageenan } \\
\lambda \text {-carrageenan }\end{array}$ & Cervical carcinoma & HeLa cell line & $\begin{array}{l}\text { Anti-cancer and } \\
\text { anti-proliferative }\end{array}$ & $\begin{array}{l}\mathrm{IC}_{50} 550.8 \mu \mathrm{g} / \mathrm{mL} \\
\mathrm{IC}_{50} 475 \mu \mathrm{g} / \mathrm{mL}\end{array}$ & $\begin{array}{l}\text { Cell cycle in } \mathrm{G} 2 / \mathrm{M} \\
\text { phase delayed } \\
\text { Hindered the cell cycle } \\
\text { in both } \mathrm{G} 1 \text { and } \mathrm{G} 2 / \mathrm{M} \\
\text { phase; } \\
\text { Cellular division } \\
\text { suppression }\end{array}$ & [203] \\
\hline $\begin{array}{l}\text { Gigartina pistillata } \\
\text { (female gametophyte) } \\
\text { Gigartina pistillata } \\
\text { (tetrasporophyte) }\end{array}$ & $\begin{array}{l}\kappa / / \text { hybrid } \\
\text { carrageenan } \\
\lambda / \xi \text { hybrid }\end{array}$ & $\begin{array}{l}\text { Colorectal } \\
\text { adenocarcinoma }\end{array}$ & $\begin{array}{l}\text { CSC-enriched } \\
\text { tumourspheres } \\
\text { and HT29, } \\
\text { SW620- and } \\
\text { SW480- derived } \\
\text { tumourspheres }\end{array}$ & $\begin{array}{l}\text { Anti-tumor and } \\
\text { anti-proliferative }\end{array}$ & $\begin{array}{l}I_{50} 0.6572 \mu \mathrm{g} / \mathrm{mL} \\
I C_{50} 0.7050 \mu \mathrm{g} / \mathrm{mL}\end{array}$ & Not Applicable & [7] \\
\hline Grateloupia filicina & $\begin{array}{l}\text { Agaran- } \\
\text { typepolysaccharide }\end{array}$ & $\mathrm{Nd}^{\star}$ & HUVECs & Anti-angiogenic & $\begin{array}{l}\text { Inhibitory ratio of } \\
28.6 \%\end{array}$ & $\begin{array}{l}\text { HUVECs } \\
\text { differentiation } \\
\text { into capillary-like } \\
\text { structures inhibition in } \\
\text { vitro and reduction of } \\
\text { migrated cells }\end{array}$ & [204] \\
\hline $\begin{array}{l}\text { Caulerpa racemosa var. } \\
\text { cylindracea }\end{array}$ & Caulerpenyne & Neuroblastoma & $\begin{array}{l}\text { HSY } 5 Y \text { and Kelly } \\
\text { cell lines }\end{array}$ & $\begin{array}{l}\text { Antiproliferative } \\
\text { and apoptotic }\end{array}$ & ${ }^{I} C_{50} 6.02 \mu \mathrm{M}$ & $\mathrm{Nd}$ & [205] \\
\hline
\end{tabular}

${ }^{*}$ Nd-not demonstrated.

According to compound chemical characterization, for example, the polysaccharides activity depends mostly from the sulphation degree and sulphate groups position, which allows the categorization of different types of carrageenan, such as $\alpha, \beta, \gamma, \theta, \imath, \kappa, \lambda, \mu$, and $\nu^{[206]}$.

As scientific evidence shows, there are various types of seaweed compounds that demonstrate activity against cancer through induction of cell death and making them anti-proliferative agents of carcinogenic cells $^{[18,34]}$.

Several studies highlight carrageenan potential for cellular inhibition, exhibiting cytotoxic effects in carcinogenic cells ${ }^{[7,203]}$. For instance, $\kappa^{-}$and $\lambda$-carrageenan showed inhibitory activity against human cervical carcinoma cells (HeLa), with an $\mathrm{IC}_{50}$ of $550.8 \mu \mathrm{g} / \mathrm{mL}$ and $475 \mu \mathrm{g} / \mathrm{mL}$, respectively ${ }^{[203]}$.

In some cases, the mechanism of action is not completely understood or revealed, which makes it dubious how the compound reacts and how it can be exploited in further assays. However, when described, seaweed 
compounds can act in different pathways of the evolution of cancer, as in proliferative signaling, cell metastasis, cell cycle, resistance to cell death, evasion, angiogenesis and evasion of growth suppressors ${ }^{[37]}$. They can also act in only one pathway or in various pathways simultaneously ${ }^{[207-210]}$.

However, between the discovery of the anti-cancer bioactivity of a compound up to the potential clinical trials, further studies are necessary to fully understand action mechanisms, benefits, and risks. This significantly reduces the potential targets into a restrictive range of compounds that can become a chemotherapy agent ${ }^{[135,211,212]}$. Moreover, these can be compounds present in very low content among seaweeds, increasing the difficulty to produce, isolate, and purify.

One of the main problems in preliminary screenings is the heterogeneity of the experimental conception and design within research studies, which do not clarify compounds and concentrations. This delivers a negative impact for further exploration due to the rigorous protocols to follow in clinical assays. Moreover, this heterogeneity can be disastrous for the knowledge acquisition and selectivity of the best compounds to be further assayed ${ }^{[41]}$. However, the US National Cancer Institute (NCI) established a standard protocol for the anti-cancer activity preclinical evaluation of compounds ${ }^{[213]}$. Such US NCI standard parameters turned necessary include evaluation of drug cytotoxic effect, drug absorption, distribution, activation, half-life, metabolism, elimination, and minimum adverse effects ${ }^{[41]}$.

Seaweed polysaccharides can also be a key to create hydrogel-based tumor models for cancer research, where it is important and vital to simulate and mimic the dynamic tumor extracellular matrix, to give the best real input of an anti-cancer drug in the affected area ${ }^{[214]}$. They could be used for a model support structure, mainly non-anionic and non-reactive calcium and/ or sodium alginate ${ }^{[214]}$. This methodology tries to substitute in vivo assays which use live animal models where the natural microenvironment of human cancer is not totally achieved.

\section{Seaweed immunotherapy compounds against cancer}

Seaweed compounds also enhance the immune system response against cancer. They have an immunomodulatory effect that is described in Table 2. The theory behind cancer immunotherapy is an activation of the immune system so it can attack and destroy target tumor cells through identification of cancer antigens ${ }^{[215]}$. The development and evaluation of new agents is important to develop safe and more effective therapies for cancer treatment ${ }^{[216,217]}$. Seaweed compounds are being described as immune regulators and stimulators which could activate the human immune cells and enhance the body's immune function $^{[218]}$.

Even as food/feed supplement, seaweed compounds show the ability to enhance the immune response to an abnormal situation in the human body, preventing or delaying the development of cancer growth ${ }^{[199,219]}$. Mainly, the response pathway is believed to be through the induction of NK and T-cell responses to the abnormal behavior. Moreover, seaweed compounds have a modulatory and protective effect in the macrophages which help prevent cancer metastasis ${ }^{[220,222,225]}$. The presented Table 2 demonstrates the potential of seaweed compounds (mainly polysaccharides, as the seaweed most known compound type) as a new and useful molecule to apply in cancer immunotherapy, in the future ${ }^{[199,222,226]}$. Nevertheless, further studies are needed until it is possible to have a safe compound for immunotherapy.

\section{Drug delivery system}

Active anti-cancer agents are commonly not administered in pure state, but rather as part of a prescribed amount where the active compound is regularly combined and encapsulated with other agents (excipients). Seaweed polysaccharides are already used in conventional drug capsulation. These can be for oral intake or intravenous therapies ${ }^{[227]}$. They can act in cancer therapy as drug delivery agents as suggested by studies 
Table 2. Seaweed compounds with immunomodulatory effect in cancer

\begin{tabular}{|c|c|c|c|c|c|c|c|}
\hline Source & Compound & Cancer & $\begin{array}{l}\text { Type of } \\
\text { assay }\end{array}$ & Concentration & Possible pathway & $\begin{array}{l}\text { Resulting } \\
\text { outcomes }\end{array}$ & Ref. \\
\hline $\begin{array}{l}\text { Undaria pinnatifida } \\
\text { sporophylls }\end{array}$ & Fucoidan & Leukemia A20 cells & In vivo mice & $\begin{array}{l}1 \% \text { of the feed } \\
10 \text { day before the } \\
\text { inoculation and } 40 \\
\text { days after }\end{array}$ & $\begin{array}{l}\text { T-cell mediated and NK cell } \\
\text { response }\end{array}$ & $\begin{array}{l}\text { Tumor destruction } \\
\text { by immune } \\
\text { response }\end{array}$ & [219] \\
\hline Sargassum hemiphyllur & nOligo-fucoidan & НСТ116 & In vitro & $50 \mathrm{mg} / \mathrm{mL}$ & $\begin{array}{l}\text { DNA damage response and } \\
\text { cell cycle checkpoint }\end{array}$ & $\begin{array}{l}\text { Prevent HCT116 } \\
\text { tumorigenicity and } \\
\text { regulate the cancer } \\
\text { cell death }\end{array}$ & [220] \\
\hline Sargassum sp. & Fucoidan & $\begin{array}{l}\text { SMMC-7721, Huh7, } \\
\text { and HCCLM3 liver }\end{array}$ & $\begin{array}{l}\text { In vivo mice } \\
\text { and in vitro }\end{array}$ & $21-33 \mathrm{mg} / \mathrm{mL}$ & $\begin{array}{l}\text { Deactivates the integrin } \\
\alpha \vee \beta 3 / S R C / E 2 F 1 \text { signaling } \\
\text { pathway }\end{array}$ & Antimetastatic & {$[221]$} \\
\hline $\begin{array}{l}\text { Nd (Sigma-Aldrich } \\
\text { (cat.22049)) }\end{array}$ & $\lambda$-carrageenan & $\begin{array}{l}\text { Melanoma B16-F10 } \\
\text { and mammary cancer } \\
\text { 4T1 }\end{array}$ & In vivo mice & $\begin{array}{l}\text { Injected every two } \\
\text { days intratumorally } \\
\text { at a dose of } 50 \\
\mathrm{mg} / \mathrm{kg}\end{array}$ & $\begin{array}{l}\text { Increase tumor-infiltrating } \\
\text { yM1 macrophages, and } \\
\text { proinflammatory cytokines }\end{array}$ & $\begin{array}{l}\text { Inhibit tumor } \\
\text { growth }\end{array}$ & {$[222]$} \\
\hline Laminaria digitata & $\begin{array}{l}\text { Laminarin (from } \\
\text { Invivogen) }\end{array}$ & $\begin{array}{l}\text { nB16-ovallbumin } \\
\text { melanoma tumor }\end{array}$ & In vivo mice & $25 \mathrm{mg} / \mathrm{kg}$ & $\begin{array}{l}\text { Enhance the production } \\
\text { cytotoxic } T \text { Iymphocyte } \\
\text { activation and interferon- } \gamma \\
\text { production }\end{array}$ & $\begin{array}{l}\text { Inhibition tumor } \\
\text { growth and } \\
\text { metastasis }\end{array}$ & [223] \\
\hline Fucus vesiculosus & Fucoidan & \multicolumn{2}{|c|}{$\begin{array}{l}\text { Human hepatoma cell/n vitro } \\
\text { line } \mathrm{MHCC}-97 \mathrm{H}\end{array}$} & $100 \mathrm{ng} / \mathrm{mL}$ & $\begin{array}{l}\text { Macrophages } \mathrm{M} 2 \text { anti- } \\
\text { inflammatory reduction }\end{array}$ & $\begin{array}{l}\text { Inhibition of tumor } \\
\text { cell migration }\end{array}$ & [224] \\
\hline
\end{tabular}

with agar, carrageenan, alginate, and fucoidan ${ }^{[172,198,228-231]}$. Seaweed polysaccharides have gained interest in this topic due to the already available know-how as they are easy to obtain and purify, cost effective, nontoxic, biodegradable, biocompatible, and easy to work with ${ }^{[172,230]}$. Also, using natural hydrophilic seaweed polysaccharides to encapsulate hydrophobic anti-cancer agents is practicable, and can diminish side effects and the dispersion of the chemotherapy agents in the human body, thus amplifying the therapeutic efficiency and efficacy ${ }^{[232]}$.

A study demonstrated the prospective effect of a hybrid hyaluronic acid-agar-based hydrogel in drug delivery in intravitreal treatments ${ }^{[233]}$. Moreover, agar injectable hydrogel with MoS2/Bi2S3-PEG (MBP), doxorubicin (DOX) can be administered in the intra-tumor area when heated ${ }^{[234]}$. Yet, when agar-based hydrogel is cooled in the administered area, it forms a static hydrogel reducing the area where the active compounds are acting ${ }^{[234]}$.

Kappa carrageenan was tested to transport curcumin in the treatment of lung cancer cells (A59) and the drug delivery system design was proven efficient ${ }^{[230]}$. Results demonstrated that the curcumin associated to a carrageenan drug delivery was more active against the cancer cells than curcumin in its free form ${ }^{[230]}$. Similarly, Lai et al. ${ }^{[232]}$ used hybrid fucoidan - Poly(lactic-co-glycolic acid) to encapsulate a hydrophobic anti-cancer compound (docetaxel).

Demonstrating the potential of seaweed polymers as drug delivery systems that can concentrate and perform a controlled release of anti-cancer compounds might also contribute to the optimization of anticancer therapy. Alginate-based hydrogels can incorporate doxorubicin and control-release the drug up to 20 days with high efficiency in vivo in mouse models ${ }^{[235-237]}$.

Alginate-based drug delivery systems can arrange self-assembled structures, such as gels in aqueous media, thus having high potential in several drug delivery applications, such as anti-cancer agent transport. The thermo-sensitive alginate hydrogels are already well investigated to be applied in drug delivery systems, such as a drug delivery system in which part of the alginate-based gel swelling could be regulated through temperature variations, leading to on-demand modulation of drug-release ${ }^{[238]}$. This can reduce the impact of the anti-cancer agent in the organism and enhance its efficacy to treat the cancer. These alginate-based gels can be loaded with simultaneous multiple drugs or sequential pre-determined delivery, where the incorporation and release kinetics need to be carefully analyzed ${ }^{[239]}$. 
Seaweed polysaccharides are the most used seaweed compounds in this area due to existing industrial and commercial exploitation. They can be low-cost, since they are chemically stable in various seaweed species commercially exploited. In terms of applicability, they are easy to apply and can be modified to different objectives besides being natural compounds, thus biocompatible.

\section{Radiotherapy and chemoprotective agents}

Protective agents are very important to protect the body against side effects of radiotherapy and chemotherapy due to debilitating effects of these types of treatment which have harmful effects in healthy cells. Some of the common problems can be immunosuppression and nauseas. The protective agents are administrated to selectively protect healthy cells from the dangerous and harmful effects of radiotherapy and chemotherapy agents ${ }^{[240]}$.

Among seaweeds, there are already studies that support a potential exploitation as protective agents with phlorotannins being the most studied ${ }^{[110]}$. The phlorotannins extract from Ecklonia cava has demonstrated a protective effect of healthy cells against radiation-induced injury and ROS-based injuries ${ }^{[241]}$. The phlorotannins eckol, dieckol, and triphlorethol-A, extracted from the Ecklonia genus, showed a multirole in protection against $\gamma$-irradiation, thus revealing an interesting potential as a protective agent in radiotherapy ${ }^{[36-39,242]}$. The mechanism of protection is designed to prevent DNA damage and lipid peroxidation.

Phlorotannins antioxidant activity is higher when compared with natural food used antioxidants, ascorbic acid, or tocopherol ${ }^{[243,244]}$, indicating an action against oxidative-induced stress and inflammatory diseases ${ }^{[24]}$. Moreover, it has been demonstrated that phlorotannins can be used as a protective agents against the toxicity of drugs in humans without diminishing the drug's effects, but fading the harm of the drug-based toxicity ${ }^{[246]}$.

Therefore, seaweed compounds can have a role in protecting the organism against the secondary effects of the therapeutics that create harmful effects in healthy cells, and, moreover, the consumption of certain species of seaweeds can have a positive effect in maintaining the organism status quo. However, there is need for further studies to support and create new protection schemes that diminish the harm of the most aggressive anti-cancer therapeutics.

\section{Seaweed compounds in pre-clinical and clinical trials to treat cancer}

Chemotherapy is the most commonly chosen therapeutic technique for cancer treatment and is the one that can have the most adverse effects in healthy cells. Nowadays, there is an enhanced quest for natural compounds due to natural existent compounds which have normally low secondary harmful reactions when compared to synthetic alternatives. This search has already given results with various molecules used in clinical cancer treatment, for example camptothecin (extracted from the tree Camptotheca acuminata) and taxol (isolated from the tree Taxus brevifolia) ${ }^{[247]}$.

In seaweeds, the development of anti-cancer therapeutic agent is in the beginning, nevertheless, there are already some compounds which are patented and in clinical trials ${ }^{[6]}$.

At a pre-clinical stage with some relevance and also some complication, there is fucoidan, a low molecular weight sulphated polysaccharide extracted from brown seaweeds. The problem holds on the difficulty to isolate only one fucoidan present in the seaweeds, but, as already demonstrated, it possesses a high anti-proliferative, antiangiogenic, and anti-cancer capacity ${ }^{[199,248,249]}$. That demonstrates how fucoidan has multiple roles against cancer cell growth and proliferation. However, this molecule varies its composition among species, but also depending on seasonality, geolocation, and maturity ${ }^{[199,250]}$. Moreover, fucoidans 
Table 3. Actual compounds from seaweeds that are already in use or in advanced clinical trials

\begin{tabular}{|c|c|c|c|c|c|}
\hline Source & Compound & Type of cancer & Activity & Resulting outcomes & Ref. \\
\hline Brown seaweed & Fucoidan & $\begin{array}{l}\text { Various types: intraductal } \\
\text { carcinoma and colorectal } \\
\text { adenocarcinoma, mainly }\end{array}$ & Chemoprotection & $\begin{array}{l}\text { Clinical trial; } 92.8 \% \text { disease control } \\
\text { rate in patients with colorectal } \\
\text { adenocarcinoma; } \\
\text { Letrozole and tamoxifen concentration } \\
\text { was not affected by the oral intake of } \\
\text { fucoidan extract; } \\
\text { Decreased fatigue and increased } \\
\text { longevity of patients undergoing } \\
\text { chemotherapy }\end{array}$ & [255-257] \\
\hline Green seaweed & Kahalalide F & Various types & Anti-cancer agent & $\begin{array}{l}\text { Clinical trial for hepatocellular carcinoma } \\
\text { treatment; } \\
\text { Induces cell death through oncosis }\end{array}$ & $a[6,258,259]$ \\
\hline Brown seaweed & Algasol T331 & Various types & $\begin{array}{l}\text { Radioprotective and } \\
\text { post-surgical adjuvant }\end{array}$ & $\begin{array}{l}\text { Clinical use; } \\
\text { Increase in physical condition } \\
\text { performance, in patients undergoing } \\
\text { surgery or radiation therapy (body } \\
\text { weight, hematic crasis and erythrocyte } \\
\text { sedimentation velocity) }\end{array}$ & {$[261]$} \\
\hline
\end{tabular}

can also have impact in reducing drug resistance by cancer cells, being a possible tool to enhance the chemotherapy compounds when cancer cells have gained resistance ${ }^{[251]}$. Thus, fucoidan can be used as an adjuvant agent in chemotherapy ${ }^{[199]}$. This compound is one of the main compounds explored as a novel anti-cancer therapeutic, due to its low toxicity and being commercially approved by different authorities around the world as a food nutritional supplement ${ }^{[248,249]}$. To be a pharmacological potential agent, there is a need to characterize and develop a method to guarantee the stability of the extracted fucoidan to do further pre-clinical studies and clinical trials ${ }^{[252]}$. In the absorption assays, fucoidan detection and measurement through oral administration is minor, so the concentration of fucoidan is inaccurately measured ${ }^{[253]}$. This way, fucoidan has not up till now been certified as a drug, consequently large-scale clinical trials cannot be carried ${ }^{[254]}$. Despite that, fucoidan related studies demonstrate that it has low toxicity and while having anti-inflammatory activity, making it a possible adjuvant compound in cancer therapy and established as a conventional treatment ${ }^{[249]}$. At a similar level, fucoxanthin, has anti-cancer activity and can be used as a drug delivery agent, but there is lack of complementary information to go to the next level ${ }^{[40]}$. There are several clinical assays with fucoidan as a food supplement and as a therapeutic agent, but the number of patients is low (maximum 54 patients) ${ }^{[199]}$. These assays demonstrate good results of fucoidan in chemoprevention as an adjuvant therapy to lower the therapeutic drug secondary effects ${ }^{[255-257]}$.

A depsipeptide denominated Kahalalide F, which is isolated from green seaweed Bryopsis sp., is patented for application in the human lung cancer and is being assayed in advanced clinical trials for the treatment of liver cancer. This compound demonstrated selectivity towards cancer cells, which creates more interest in testing against various types of cancer to check the range of the potential usage ${ }^{[6,258,259]}$. Patient response was good without inducing acute responses to treatment, unlike the conventional treatment ${ }^{[260]}$. Moreover, advanced cancer stages seemed to have stabilized in some of the analyzed patients ${ }^{[260]}$.

In cancer treatment, there is an old compound, based in brown seaweed phycocolloid (Algasol T331), which was used at clinical stage studies with human patients ${ }^{[261]}$. The benefits of this compound was in the post-surgery management and after radiotherapy of oncology patients ${ }^{[261]}$. The compounds' main effects were protecting the human body and allowing it to recover faster from more intensive and harmful cancer therapy, mainly in the recovery of hematic function and reduction of asthenia ${ }^{[261]}$.

However, there is a long road from the screening of bioactive compounds which have anti-cancer properties or permit to use in new therapies, until clinical applications. At the moment, seaweed compounds are mainly in pre-clinical assays so that the best compounds can be tested in clinical trials (pre-clinical - Tables 1 and 2 ; clinical - Table 3$)^{[18]}$. 


\section{CONCLUSION}

Seaweed consumption can have benefits in the cancer prevention and treatment, yet there is need for more knowledge regarding seaweed nutritional and compounds profiles if to be used as food supplements with health benefits. Otherwise, depending on the dose, seaweed consumption can be a problem to human health.

In cancer therapeutic, there are preliminary studies demonstrating seaweed's potential against cancer, playing diverse roles in cancer therapy. However, due to the surrounding ecosystem that seaweeds inhabit, there are complex methods to extract and guarantee target compounds' chemical stability and quality. This way, there is a need to surpass this problem through the production of seaweeds in cultivation systems to guarantee the target quality in all the seaweed biomass produced and which cannot be replicated in the natural habitat, especially with seaweed secondary metabolites.

\section{DECLARATIONS}

\section{Acknowledgments}

This work was financed by national funds through FCT (Foundation for Science and Technology), I.P., within the scope of the projects UIDB/04292/2020 (MARE, Marine and Environmental Sciences Centre) and UIDP/50017/2020+UIDB/50017/2020 (CESAM, Centre for Environmental and Marine Studies). João Cotas thanks to the European Regional Development Fund through the Interreg Atlantic Area Program, under the project NASPA (EAPA_451/2016). Diana Pacheco thanks to PTDC/BIA-CBI/31144/2017POCI-01 project -0145-FEDER-031144-MARINE INVADERS, co-financed by the ERDF through POCI (Operational Program Competitiveness and Internationalization) and by the Foundation for Science and Technology (FCT, IP). A. M. M. Gonçalves thanks to the project MENU - Marine Macroalgae: Alternative recipes for a daily nutritional diet (FA_05_2017_011) funded by the Blue Fund under Public Notice No. 5 - Blue Biotechnology. Ana M. M. Gonçalves also acknowledges University of Coimbra for the contract IT057-18-7253. Paulo Silva's work was supported by the Applied Molecular Biosciences Unit - UCIBIO which is financed by national funds from FCT (UIDB/04378/2020).

\section{Authors' contributions}

Review conceptualization: Cotas J, Pacheco D, Gonçalves AMM, Pereira L

Review preparation: Cotas J, Pacheco D, Gonçalves AMM, Silva P, Carvalho LG

Review writing, review and editing: Cotas J, Pacheco D, Gonçalves AMM, Silva P, Carvalho LG, Pereira L All authors have read and agreed to the published version of the manuscript.

\section{Availability of data and materials}

Not applicable.

\section{Financial support and sponsorship}

None.

\section{Conflicts of interest}

All authors declared that there are no conflicts of interest.

\section{Ethical approval and consent to participate}

Not applicable.

\section{Consent for publication}

Not applicable. 


\section{Copyright}

(c) The Author(s) 2021.

\section{REFERENCES}

1. Sheikh I, Sharma V, Tuli HS, Aggarwal D, Sankhyan A, Vyas P, et al. Cancer Chemoprevention by Flavonoids, Dietary Polyphenols and Terpenoids. Biointerface Res Appl Chem 2020;11:8502-37.

2. Vignesh S, Raja A, Arthur Jam R. Marine Drugs: Implication and Future Studies. Int J Pharmacol 2010;7:22-30.

3. King RJB, Robins MW. Cancer biology. Harlow, Essex, UK: Pearson Prentice Hall; 2006.

4. Ruan BF, Ge WW, Lin MX, Li QS. A Review of the Components of Seaweeds as Potential Candidates in Cancer Therapy. Anticancer Agents Med Chem 2018;18:354-66.

5. Bray F, Ferlay J, Soerjomataram I, Siegel RL, Torre LA, Jemal A. Global cancer statistics 2018: GLOBOCAN estimates of incidence and mortality worldwide for 36 cancers in 185 countries. CA Cancer J Clin 2018;68:394-424.

6. Brown EM, Allsopp PJ, Magee PJ, et al. Seaweed and human health. Nutr Rev 2014;72:205-16.

7. Cotas J, Marques V, Afonso MB, Rodrigues CMP, Pereira L. Antitumour Potential of Gigartina pistillata Carrageenans against Colorectal Cancer Stem Cell-Enriched Tumourspheres. Mar Drugs 2020;18:50.

8. Parkin DM, Bray F, Ferlay J, Pisani P. Global cancer statistics, 2002. CA Cancer J Clin 2005;55:74-108.

9. Gersten O, Wilmoth JR. The Cancer Transition in Japan since 1951. DemRes 2002;7:271-306.

10. Maule M, Merletti F. Cancer transition and priorities for cancer control. Lancet Oncol 2012;13:745-6.

11. Chinnababu B, Purushotham Reddy S, Sankara Rao P, et al. Isolation, semi-synthesis and bio-evaluation of spatane derivatives from the brown algae Stoechospermum marginatum. Bioorg Med Chem Lett 2015;25:2479-83.

12. Déléris P, Nazih H, Bard J. Seaweeds in Human Health. Seaweed in Health and Disease Prevention. Elsevier; 2016. pp. 319-67.

13. Kolb N, Vallorani L, Milanović N, Stocchi V. Evaluation of Marine Algae Wakame (Undaria pinnatifida) and Kombu (Laminaria digitata japonica) as Food Supplements. Food Technol Biotechnol 2004;42:57-61.

14. Taboada MC, Millán R, Miguez MI. Nutritional value of the marine algae wakame (Undaria pinnatifida) and nori (Porphyra purpurea) as food supplements. J Appl Phycol 2013;25:1271-6.

15. Pereira L. Seaweeds as source of bioactive substances and skin care therapy-Cosmeceuticals, algotheraphy, and thalassotherapy. Cosmetics 2018;5:68.

16. García-Poza S, Leandro A, Cotas C, et al. The Evolution Road of Seaweed Aquaculture: Cultivation Technologies and the Industry 4.0. Int J Environ Res Public Health 2020;17:6528.

17. Ruperez P. Mineral content of edible marine seaweeds. Food Chem 2002;79:23-6.

18. Wali AF, Majid S, Rasool S, et al. Natural products against cancer: Review on phytochemicals from marine sources in preventing cancer. Saudi Pharm J 2019;27:767-77.

19. Leandro A, Pereira L, Gonçalves AMM. Diverse Applications of Marine Macroalgae. Mar Drugs 2019;18:17.

20. Kim SK. Handbook of Marine Macroalgae. Chichester, UK: John Wiley \& Sons, Ltd; 2011.

21. Francavilla M, Franchi M, Monteleone M, Caroppo C. The red seaweed Gracilaria gracilis as a multi products source. Mar Drugs 2013;11:3754-76.

22. Giordano M, Beardall J, Raven JA. CO2 concentrating mechanisms in algae: mechanisms, environmental modulation, and evolution. Annu Rev Plant Biol 2005;56:99-131.

23. Rodrigues D, Freitas AC, Pereira L, et al. Chemical composition of red, brown and green macroalgae from Buarcos bay in Central West Coast of Portugal. Food Chem 2015;183:197-207.

24. Shannon E, Abu-ghannam N. Seaweeds as nutraceuticals for health and nutrition. Phycologia 2019;58:563-77.

25. Nunes N, Valente S, Ferraz S, Barreto MC, Pinheiro de Carvalho MAA. Nutraceutical potential of Asparagopsis taxiformis (Delile) Trevisan extracts and assessment of a downstream purification strategy. Heliyon 2018;4:e00957.

26. Pereira L. Edible Seaweeds of the World. Boca Raton, FL, USA: CRC Press; 2016.

27. Rajapakse N, Kim S. Nutritional and Digestive Health Benefits of Seaweed. Marine Medicinal Foods - Implications and Applications, Macro and Microalgae. Elsevier; 2011. pp. 17-28.

28. Mišurcová L, Machů L, Orsavová J. Seaweed Minerals as Nutraceuticals. Marine Medicinal Foods - Implications and Applications, Macro and Microalgae. Elsevier; 2011. pp. 371-90.

29. Černá M. Seaweed proteins and amino acids as nutraceuticals. In: Kim SK, editor. Advances in food and nutrition research. San Diego: Academic Press; 2011. pp. 297-312.

30. Macartain P, Gill CI, Brooks M, Campbell R, Rowland IR. Nutritional Value of Edible Seaweeds. Nutr Rev 2007;65:535-43.

31. Ganesan AR, Tiwari U, Rajauria G. Seaweed nutraceuticals and their therapeutic role in disease prevention. Food Sci Hum Wellness 2019;8:252-63.

32. Tanna B, Mishra A. Metabolites Unravel Nutraceutical Potential of Edible Seaweeds: An Emerging Source of Functional Food. Compr Rev Food Sci Food Saf 2018;17:1613-24.

33. Lopes G, Sousa C, Valentão P, Andrade PB. Sterols in Algae and Health. In: Hernández-ledesma B, Herrero M, editors. Bioactive Compounds from Marine Foods. Chichester: John Wiley \& Sons Ltd; 2013. pp. 173-91.

34. Alves C, Silva J, Pinteus S, et al. From Marine Origin to Therapeutics: The Antitumor Potential of Marine Algae-Derived Compounds. Front Pharmacol 2018;9:777. 
35. Leandro A, Pacheco D, Cotas J, Marques JC, Pereira L, Gonçalves AMM. Seaweed's Bioactive Candidate Compounds to Food Industry and Global Food Security. Life (Basel) 2020;10:140.

36. Moon C, Kim SH, Kim JC, et al. Protective effect of phlorotannin components phloroglucinol and eckol on radiation-induced intestinal injury in mice. Phytother Res 2008;22:238-42.

37. Park E, Ahn G, Yun JS, et al. Dieckol rescues mice from lethal irradiation by accelerating hemopoiesis and curtailing immunosuppression. Int J Radiat Biol 2010;86:848-59.

38. Zhang R, Kang KA, Piao MJ, et al. Eckol protects V79-4 lung fibroblast cells against gamma-ray radiation-induced apoptosis via the scavenging of reactive oxygen species and inhibiting of the c-Jun NH(2)-terminal kinase pathway. Eur J Pharmacol 2008;591:114-23.

39. Kang KA, Zhang R, Lee KH, et al. Protective effect of triphlorethol-A from Ecklonia cava against ionizing radiation in vitro. $J$ Radiat Res 2006;47:61-8.

40. Wang Z, Li H, Dong M, Zhu P, Cai Y. The anticancer effects and mechanisms of fucoxanthin combined with other drugs. J Cancer Res Clin Oncol 2019;145:293-301.

41. Gutiérrez-Rodríguez AG, Juárez-Portilla C, Olivares-Bañuelos T, Zepeda RC. Anticancer activity of seaweeds. Drug Discov Today 2018;23:434-47.

42. Jiang J, Shi S. Seaweeds and Cancer Prevention. Bioactive Seaweeds for Food Applications. Elsevier; 2018. pp. 269-90.

43. Rocha DHA, Seca AML, Pinto DCGA. Seaweed Secondary Metabolites In Vitro and In Vivo Anticancer Activity. Mar Drugs 2018;16:410.

44. Ismail MM, Alotaibi BS, El-Sheekh MM. Therapeutic Uses of Red Macroalgae. Molecules 2020;25:4411.

45. Murphy C, Hotchkiss S, Worthington J, Mckeown SR. The potential of seaweed as a source of drugs for use in cancer chemotherapy. $J$ Appl Phycol 2014;26:2211-64.

46. Kumar CS, Ganesan P, Suresh P V., Bhaskar N. Seaweeds as a source of nutritionally beneficial compounds - a review. J Food Sci Technol 2008;45:1-13.

47. Cherry P, O’Hara C, Magee PJ, McSorley EM, Allsopp PJ. Risks and benefits of consuming edible seaweeds. Nutr Rev 2019;77:307-29.

48. Ferdouse F, Løvstad Holdt S, Smith R, Murúa P, Yang Z. The global status of seaweed production, trade and utilization. FAO Globefish Res Program 2018;124:120.

49. Babahan I, Kirim B, Mehr H. Major Natural Vegetation in Coastal and Marine Wetlands: Edible Seaweeds. In: T. Oliveira M, Candan F, Fernandes-silva A, editors. Plant Communities and Their Environment. IntechOpen; 2020.

50. Novaczek I, Athy A. Sea vegetable recipes for the Pacific Islands. The University of the South Pacific; 2001.

51. Unidade de Bioquímica M. Seaweed Recipes. 2020. Available from https://www.ubqmadeira.com/en/category/receitas/. [Last accessed on 5 Mar 2021]

52. Pacheco D, Araújo GS, Cotas J, Gaspar R, Neto JM, Pereira L. Invasive Seaweeds in the Iberian Peninsula: A Contribution for Food Supply. Mar Drugs 2020;18:560.

53. Park Y, Lee J, Oh JH, Shin A, Kim J. Dietary patterns and colorectal cancer risk in a Korean population: A case-control study. Medicine (Baltimore) 2016;95:e3759.

54. Nelson SM, Gao YT, Nogueira LM, et al. Diet and biliary tract cancer risk in Shanghai, China. PLoS One 2017;12:e0173935.

55. Jemal A, Bray F, Center MM, Ferlay J, Ward E, Forman D. Global cancer statistics. CA Cancer J Clin 2011;61:69-90.

56. Ferlay J, Parkin DM, Steliarova-Foucher E. Estimates of cancer incidence and mortality in Europe in 2008. Eur J Cancer 2010;46:76581.

57. Drewnowski A, Popkin BM. The nutrition transition: new trends in the global diet. Nutr Rev 1997;55:31-43.

58. Wahlqvist M, Kouris-Blazos A, Crotty P, Worsley T, Harvey P, Tieru H C-SL. Health and nutritional needs in the western pacific: culturally related areas which may be addressed by FBDGs. In: WHO Regional Office for the Western Pacific, editor. Development of food-based dietary guidelines for the Western Pacific region. WHO Region. Manila, Philippines: World Health Organization; 1999. p. 1931.

59. Iso H, Kubota Y, Japan Collaborative Cohort Study for Evaluation of Cancer. Nutrition and disease in the Japan Collaborative Cohort Study for Evaluation of Cancer (JACC). Asian Pac J Cancer Prev 2007;8 Suppl:35-80.

60. Sá Monteiro M, Sloth J, Holdt S, Hansen M; National Food Institute, Technical University of Denmark, Denmark. Analysis and Risk Assessment of Seaweed. EFSA J 2019;17:e170915.

61. Ownsworth E, Selby D, Ottley CJ, et al. Tracing the natural and anthropogenic influence on the trace elemental chemistry of estuarine macroalgae and the implications for human consumption. Sci Total Environ 2019;685:259-72.

62. Teas J, Braverman LE, Kurzer MS, Pino S, Hurley TG, Hebert JR. Seaweed and soy: companion foods in Asian cuisine and their effects on thyroid function in American women. J Med Food 2007;10:90-100.

63. Fleurence J. Seaweed proteins. Trends Food Sci Technol 1999;10:25-8.

64. Ramu Ganesan A, Subramani K, Shanmugam M, et al. A comparison of nutritional value of underexploited edible seaweeds with recommended dietary allowances. J King Saud Univ - Sci 2020;32:1206-11.

65. Kalasariya, H.S., Patel, R.V., Pandya, K.Y., Jasrai, R.T. Brahmbhatt NH. A review on nutritional facets of seaweeds. Int J Chem Sci Tech 2016;1:27-32.

66. Syad AN, Shunmugiah KP, Kasi PD. Seaweeds as nutritional supplements: Analysis of nutritional profile, physicochemical properties and proximate composition of G. acerosa and S. wightii. Biomed Prev Nutr 2013;3:139-44.

67. Balagopal P, George D, Patton N, et al. Lifestyle-only intervention attenuates the inflammatory state associated with obesity: a randomized controlled study in adolescents. J Pediatr 2005;146:342-8. 
68. Wong K, Cheung PC. Nutritional evaluation of some subtropical red and green seaweeds. Food Chem 2000;71:475-82.

69. Klop B, Elte JW, Cabezas MC. Dyslipidemia in obesity: mechanisms and potential targets. Nutrients 2013;5:1218-40.

70. Al-Khalaifah H. Modulatory Effect of Dietary Polyunsaturated Fatty Acids on Immunity, Represented by Phagocytic Activity. Front Vet Sci 2020;7:569939.

71. Patarra RF, Paiva L, Neto AI, Lima E, Baptista J. Nutritional value of selected macroalgae. J Appl Phycol 2011;23:205-8.

72. Matsumura Y. Nutrition trends in Japan. Asia Pac J Clin Nutr 2001;10:S40-7.

73. Murai U, Yamagishi K, Sata M, et al; JPHC Study Group. Seaweed intake and risk of cardiovascular disease: the Japan Public Health Center-based Prospective (JPHC) Study. Am J Clin Nutr 2019;110:1449-55.

74. Bhutta Z, Sadiq K. Protein Deficiency. Encyclopedia of Human Nutrition. Elsevier; 2013. pp. 111-5.

75. Heymsfield SB, Avena NM, Baier L, et al. Hyperphagia: current concepts and future directions proceedings of the 2nd international conference on hyperphagia. Obesity (Silver Spring) 2014;22 Suppl 1:S1-S17.

76. Rosenbaum M, Leibel RL. Adaptive thermogenesis in humans. Int J Obes (Lond) 2010;34 Suppl 1:S47-55.

77. Madhusudan C, Manoj S, Rahul K, Rishi CM. Seaweeds: A Diet with Nutritional, Medicinal and Industrial Value. Res J Med Plant 2011;5:153-7.

78. Guo F, Huang C, Cui Y, Momma H, Niu K, Nagatomi R. Dietary seaweed intake and depressive symptoms in Japanese adults: a prospective cohort study. Nutr $J$ 2019;18:58.

79. Machado M, Machado S, Pimentel FB, Freitas V, Alves RC, Oliveira MBPP. Amino Acid Profile and Protein Quality Assessment of Macroalgae Produced in an Integrated Multi-Trophic Aquaculture System. Foods 2020;9:1382.

80. Percival E, Smestad B. Photosynthetic studies on Ulva lactuca. Phytochemistry 1972;11:1967-72.

81. Kadam SU, Tiwari BK, O'donnell CP. Extraction, structure and biofunctional activities of laminarin from brown algae. Int J Food Sci Technol 2015;50:24-31.

82. Devillé C, Damas J, Forget P, Dandrifosse G, Peulen O. Laminarin in the dietary fibre concept. J Sci Food Agric 2004;84:1030-8.

83. Valado A, Pereira M, Caseiro A, et al. Effect of Carrageenans on Vegetable Jelly in Humans with Hypercholesterolemia. Mar Drugs 2019;18:19.

84. Cardoso I, Cotas J, Rodrigues A, Ferreira D, Osório N, Pereira L. Extraction and Analysis of Compounds with Antibacterial Potential from the Red Alga Grateloupia turuturu. JMSE 2019;7:220.

85. Zhang Z, Zhang Q, Wang J, Song H, Zhang H, Niu X. Regioselective syntheses of sulfated porphyrans from Porphyra haitanensis and their antioxidant and anticoagulant activities in vitro. Carbohydrate Polymers 2010;79:1124-9.

86. Zargarzadeh M, Amaral AJR, Custódio CA, Mano JF. Biomedical applications of laminarin. Carbohydr Polym 2020;232:115774.

87. Sony NM, Ishikawa M, Hossain MS, Koshio S, Yokoyama S. The effect of dietary fucoidan on growth, immune functions, blood characteristics and oxidative stress resistance of juvenile red sea bream, Pagrus major. Fish Physiol Biochem 2019;45:439-54.

88. Cui H, Wang Z, Liu J, et al. Effects of a highly purified fucoidan from Undaria pinnatifida on growth performance and intestine health status of gibel carp Carassius auratus gibelio. Aquacult Nutr 2019;26:47-59.

89. Nagamine T, Nakazato K, Tomioka S, Iha M, Nakajima K. Intestinal absorption of fucoidan extracted from the brown seaweed, Cladosiphon okamuranus. Mar Drugs 2014;13:48-64.

90. Zhao X, Guo F, Hu J, et al. Antithrombotic activity of oral administered low molecular weight fucoidan from Laminaria Japonica. Thromb Res 2016;144:46-52.

91. Wu SY, Parasuraman V, Hsieh-Chih-Tsai, et al. Radioprotective effect of self-assembled low molecular weight Fucoidan-Chitosan nanoparticles. Int J Pharm 2020;579:119161.

92. Brownlee IA, Allen A, Pearson JP, et al. Alginate as a source of dietary fiber. Crit Rev Food Sci Nutr 2005;45:497-510.

93. Teas J, Vena S, Cone DL, Irhimeh M. The consumption of seaweed as a protective factor in the etiology of breast cancer: proof of principle. J Appl Phycol 2013;25:771-9.

94. Padayatty SJ, Katz A, Wang Y, et al. Vitamin C as an antioxidant: evaluation of its role in disease prevention. J Am Coll Nutr 2003;22:1835 .

95. Kong X, Du L, Du G. Vitamin A. Natural Small Molecule Drugs from Plants. Singapore: Springer; 2018. pp. 627-31.

96. Allen L, Benoist B De, Dary O, Hurrell R, Horton S, Lewis J, et al. Guidelines on food fortification with micronutrients. World Heal. Geneva, Switzerland: World Health Organization Press; 2006.

97. Mora JR, Iwata M, von Andrian UH. Vitamin effects on the immune system: vitamins A and D take centre stage. Nat Rev Immunol 2008;8:685-98.

98. Pereira L. A review of the nutrient composition of selected edible seaweeds. In: Pomin VH, editor. Seaweed: Ecology, Nutrient Composition and Medicinal Uses. Hauppauge, NY, USA: Nova Science Publishers, Inc.; 2011. p. 15-47.

99. Miyashita K, Mikami N, Hosokawa M. Chemical and nutritional characteristics of brown seaweed lipids: A review. J Funct Foods 2013;5:1507-17.

100. Watzl B, Kulling SE, Möseneder J, Barth SW, Bub A. A 4-wk intervention with high intake of carotenoid-rich vegetables and fruit reduces plasma C-reactive protein in healthy, nonsmoking men. Am J Clin Nutr 2005;82:1052-8.

101. Stead SM. Rethinking marine resource governance for the United Nations Sustainable Development Goals. Curr Opin Environ Sustain 2018;34:54-61.

102. Vieira EF, Soares C, Machado S, et al. Seaweeds from the Portuguese coast as a source of proteinaceous material: Total and free amino acid composition profile. Food Chem 2018;269:264-75.

103. Maeda H, Yamamoto R, Hirao K, Tochikubo O. Effects of agar (kanten) diet on obese patients with impaired glucose tolerance and type 2 
diabetes. Diabetes Obes Metab 2005;7:40-6.

104. Mysliwa-Kurdziel B, Solymosi K. Phycobilins and Phycobiliproteins Used in Food Industry and Medicine. Mini Rev Med Chem 2017;17:1173-93.

105. Viera I, Pérez-Gálvez A, Roca M. Bioaccessibility of Marine Carotenoids. Mar Drugs 2018;16:397.

106. Galasso C, Corinaldesi C, Sansone C. Carotenoids from Marine Organisms: Biological Functions and Industrial Applications. Antioxidants (Basel) 2017;6:96.

107. Boominathan, M. and Mahesh A. Seaweed Carotenoids for Cancer Therapeutics. In: Kim S-K, editor. Handbook of Anticancer Drugs from Marine Origin. Cham, Switzerland: Springer International Publishing Switzerland; 2015. p. 185-203.

108. Kotake-Nara E, Terasaki M, Nagao A. Characterization of apoptosis induced by fucoxanthin in human promyelocytic leukemia cells. Biosci Biotechnol Biochem 2005;69:224-7.

109. Gupta S, Abu-ghannam N. Recent developments in the application of seaweeds or seaweed extracts as a means for enhancing the safety and quality attributes of foods. Innov Food Sci Emerg Technol 2011;12:600-9.

110. Peñalver R, Lorenzo JM, Ros G, Amarowicz R, Pateiro M, Nieto G. Seaweeds as a Functional Ingredient for a Healthy Diet. Mar Drugs 2020;18:301.

111. Félix R, Carmona AM, Félix C, Novais SC, Lemos MFL. Industry-Friendly Hydroethanolic Extraction Protocols for Grateloupia turuturu UV-Shielding and Antioxidant Compounds. Appl Sci 2020;10:5304.

112. Eriksen NT. Production of phycocyanin--a pigment with applications in biology, biotechnology, foods and medicine. Appl Microbiol Biotechnol 2008;80:1-14.

113. Stengel DB, Connan S, Popper ZA. Algal chemodiversity and bioactivity: sources of natural variability and implications for commercial application. Biotechnol Adv 2011;29:483-501.

114. Nguyen HPT, Morançais M, Déléris P, et al. Purification of R-phycoerythrin from a marine macroalga Gracilaria gracilis by anionexchange chromatography. J Appl Phycol 2020;32:553-61.

115. Yu P, Wu Y, Wang G, Jia T, Zhang Y. Purification and bioactivities of phycocyanin. Crit Rev Food Sci Nutr 2017;57:3840-9.

116. Pardhasaradhi BV V, Ali AM, Kumari AL, Reddanna P, Khar A. Phycocyanin-mediated apoptosis in AK-5 tumor cells involves downregulation of Bcl-2 and generation of ROS. Mol Cancer Ther 2003;2:1165-70.

117. Jaiswal P, Singh PK, Prasanna R. Cyanobacterial bioactive molecules--an overview of their toxic properties. Can J Microbiol 2008;54:701-17.

118. Li W, Su HN, Pu Y, et al. Phycobiliproteins: molecular structure, production, applications, and prospects. Biotechnol Adv 2019;37:340-53.

119. Reddy MC, Subhashini J, Mahipal S, et al. C-Phycocyanin, a selective cyclooxygenase-2 inhibitor, induces apoptosis in lipopolysaccharidestimulated RAW 264.7 macrophages. Biochem Biophys Res Commun 2003;304:385-92.

120. Shih SR, Tsai KN, Li YS, Chueh CC, Chan EC. Inhibition of enterovirus 71-induced apoptosis by allophycocyanin isolated from a bluegreen alga Spirulina platensis. J Med Virol 2003;70:119-25.

121. Nagaraj S, Arulmurugan P, Rajaram M, et al. Hepatoprotective and antioxidative effects of C-phycocyanin from Arthrospira maxima SAG 25780 in CCl4-induced hepatic damage rats. Biomed Prev Nutr 2012;2:81-5.

122. Di Tomo P, Canali R, Ciavardelli D, et al. $\beta$-Carotene and lycopene affect endothelial response to TNF- $\alpha$ reducing nitro-oxidative stress and interaction with monocytes. Mol Nutr Food Res 2012;56:217-27.

123. Gori T, Münzel T. Oxidative stress and endothelial dysfunction: therapeutic implications. Ann Med 2011;43:259-72.

124. Guedes AC, Amaro HM, Malcata FX. Microalgae as sources of carotenoids. Mar Drugs 2011;9:625-44.

125. Gao S, Qin T, Liu Z, Caceres MA, Ronchi CF, Chen C-YO, et al. Lutein and zeaxanthin supplementation reduces H2O2-induced oxidative damage in human lens epithelial cells. Mol Vis 2011;17:3180-90.

126. Christaki E, Bonos E, Giannenas I, Florou-Paneri P. Functional properties of carotenoids originating from algae. J Sci Food Agric 2013;93:5-11.

127. Parjikolaei BR, Bruhn A, Eybye KL, et al. Valuable Biomolecules from Nine North Atlantic Red Macroalgae: Amino Acids, Fatty Acids, Carotenoids, Minerals and Metals. Natural Resources 2016;07:157-83.

128. Audibert L, Fauchon M, Blanc N, Hauchard D, Gall EA. Phenolic compounds in the brown seaweed Ascophyllum nodosum: distribution and radical-scavenging activities. Phytochem Anal 2010;21:399-405.

129. Generalić Mekinić I, Skroza D, Šimat V, Hamed I, Čagalj M, Popović Perković Z. Phenolic Content of Brown Algae (Pheophyceae) Species: Extraction, Identification, and Quantification. Biomolecules 2019;9:244.

130. Gómez-Guzmán M, Rodríguez-Nogales A, Algieri F, Gálvez J. Potential Role of Seaweed Polyphenols in Cardiovascular-Associated Disorders. Mar Drugs 2018;16:250.

131. Chen Y, Lin H, Li Z, Mou Q. The anti-allergic activity of polyphenol extracted from five marine algae. J Ocean Univ China 2015;14:6814.

132. Murray M, Dordevic AL, Ryan L, Bonham MP. The Impact of a Single Dose of a Polyphenol-Rich Seaweed Extract on Postprandial Glycaemic Control in Healthy Adults: A Randomised Cross-Over Trial. Nutrients 2018;10:270.

133. Pangestuti R, Kim SK. Neuroprotective effects of marine algae. Mar Drugs 2011;9:803-18.

134. Holdt SL, Kraan S. Bioactive compounds in seaweed: functional food applications and legislation. J Appl Phycol 2011;23:543-97.

135. Liu M, Hansen PE, Lin X. Bromophenols in marine algae and their bioactivities. Mar Drugs 2011;9:1273-92.

136. Thomas NV, Kim SK. Potential pharmacological applications of polyphenolic derivatives from marine brown algae. Environ Toxicol Pharmacol 2011;32:325-35.

137. Tanna B, Brahmbhatt HR, Mishra A. Phenolic, flavonoid, and amino acid compositions reveal that selected tropical seaweeds have the 
potential to be functional food ingredients. J Food Process Preserv 2019;43.

138. Nwosu F, Morris J, Lund VA, Stewart D, Ross HA, Mcdougall GJ. Anti-proliferative and potential anti-diabetic effects of phenolic-rich extracts from edible marine algae. Food Chem 2011;126:1006-12.

139. Lopes G, Sousa C, Silva LR, et al. Can phlorotannins purified extracts constitute a novel pharmacological alternative for microbial infections with associated inflammatory conditions? PLoS One 2012;7:e31145.

140. Urquiaga I, Leighton F. Plant polyphenol antioxidants and oxidative stress. Biol Res 2000;33:55-64.

141. Pereira L. Therapeutic and Nutritional Uses of Algae. Boca Raton, FL, USA: CRC Press; 2018.

142. Ravikumar S, Jacob Inbaneson S, Suganthi P. Seaweeds as a source of lead compounds for the development of new antiplasmodial drugs from South East coast of India. Parasitol Res 2011;109:47-52.

143. Schultz JC, Hunter MD, Appel HM. Antimicrobial Activity of Polyphenols Mediates Plant-Herbivore Interactions. In: Hemingway RW, Laks PE, editors. Plant Polyphenols. Boston, MA, USA: Springer US; 1992. pp. 621-37.

144. Maqsood S, Benjakul S, Shahidi F. Emerging role of phenolic compounds as natural food additives in fish and fish products. Crit Rev Food Sci Nutr 2013;53:162-79.

145. Panzella L, Napolitano A. Natural Phenol Polymers: Recent Advances in Food and Health Applications. Antioxidants (Basel) 2017;6:30.

146. Wang T, Jónsdóttir R, Kristinsson HG, et al. Inhibition of haemoglobin-mediated lipid oxidation in washed cod muscle and cod protein isolates by Fucus vesiculosus extract and fractions. Food Chem 2010;123:321-30.

147. Chakraborty K, Joseph D, Praveen NK. Antioxidant activities and phenolic contents of three red seaweeds (Division: Rhodophyta) harvested from the Gulf of Mannar of Peninsular India. J Food Sci Technol 2015;52:1924-35.

148. Xu T, Sutour S, Casabianca H, et al. Rapid Screening of Chemical Compositions of Gracilaria dura and Hypnea mucisformis (Rhodophyta) from Corsican Lagoon. Intl J Phyto Natu Ingrd 2015;2:8.

149. Tomaz ACDA, Miranda GECD, Souza MDFVD, da Cunha EVL. Analysis and characterization of methyl esters of fatty acids of some Gracilaria species. Biochem Syst Ecol 2012;44:303-6.

150. Santos SA, Vilela C, Freire CS, Abreu MH, Rocha SM, Silvestre AJ. Chlorophyta and Rhodophyta macroalgae: a source of health promoting phytochemicals. Food Chem 2015;183:122-8.

151. Oren A, Gunde-Cimerman N. Mycosporines and mycosporine-like amino acids: UV protectants or multipurpose secondary metabolites? FEMS Microbiol Lett 2007;269:1-10.

152. De Flora S, Ferguson LR. Overview of mechanisms of cancer chemopreventive agents. Mutat Res 2005;591:8-15.

153. Lee SB, Lee JY, Song DG, Pan CH, Nho CW, Kim M-C, et al. Cancer chemopreventive effects of Korean seaweed extracts. Food Sci Biotechnol 2008; 17:613-22.

154. Teas J. Dietary Seaweed and Breast Cancer: A Randomized Trial. Columbia, SC, USA; 2005.

155. Minami Y, Kanemura S, Oikawa T, et al. Associations of Japanese food intake with survival of stomach and colorectal cancer: A prospective patient cohort study. Cancer Sci 2020;111:2558-69.

156. Zhang X, Aweya JJ, Huang ZX, et al. In vitro fermentation of Gracilaria lemaneiformis sulfated polysaccharides and its agarooligosaccharides by human fecal inocula and its impact on microbiota. Carbohydr Polym 2020;234:115894.

157. Zheng LX, Chen XQ, Cheong KL. Current trends in marine algae polysaccharides: The digestive tract, microbial catabolism, and prebiotic potential. Int J Biol Macromol 2020;151:344-54.

158. Gurpilhares DB, Cinelli LP, Simas NK, Pessoa A Jr, Sette LD. Marine prebiotics: Polysaccharides and oligosaccharides obtained by using microbial enzymes. Food Chem 2019;280:175-86.

159. Scharlau D, Borowicki A, Habermann N, et al. Mechanisms of primary cancer prevention by butyrate and other products formed during gut flora-mediated fermentation of dietary fibre. Mutat Res 2009;682:39-53.

160. Chen HM, Yu YN, Wang JL, et al. Decreased dietary fiber intake and structural alteration of gut microbiota in patients with advanced colorectal adenoma. Am J Clin Nutr 2013;97:1044-52.

161. Abreu MT, Peek RM Jr. Gastrointestinal malignancy and the microbiome. Gastroenterology 2014;146:1534-1546.e3.

162. Song M, Wu K, Meyerhardt JA, et al. Fiber Intake and Survival After Colorectal Cancer Diagnosis. JAMA Oncol 2018;4:71-9.

163. Teas J. The dietary intake of Laminaria, a brown seaweed, and breast cancer prevention. Nutr Cancer 1983;4:217-22.

164. Funahashi H, Imai T, Tanaka Y, et al. Suppressive effect of iodine on DMBA-induced breast tumor growth in the rat. J Surg Oncol 1996;61:209-13.

165. Funahashi H, Imai T, Tanaka Y, et al. Wakame seaweed suppresses the proliferation of 7,12-dimethylbenz(a)-anthracene-induced mammary tumors in rats. Jpn J Cancer Res 1999;90:922-7.

166. Funahashi H, Imai T, Mase T, et al. Seaweed prevents breast cancer? Jpn J Cancer Res 2001;92:483-7.

167. Cherry P, Yadav S, Strain CR, et al. Prebiotics from Seaweeds: An Ocean of Opportunity? Mar Drugs 2019;17:327.

168. Yang YJ, Nam SJ, Kong G, Kim MK. A case-control study on seaweed consumption and the risk of breast cancer. Br J Nutr 2010;103:1345-53.

169. Lopez-Santamarina A, Miranda JM, Mondragon ADC, et al. Potential Use of Marine Seaweeds as Prebiotics: A Review. Molecules 2020;25:1004.

170. Cotas J, Leandro A, Pacheco D, Gonçalves AMM, Pereira L. A Comprehensive Review of the Nutraceutical and Therapeutic Applications of Red Seaweeds (Rhodophyta). Life (Basel) 2020;10:19.

171. Cotas J, Leandro A, Monteiro P, et al. Seaweed Phenolics: From Extraction to Applications. Mar Drugs 2020;18:384.

172. Pereira L, Cotas J. Introductory Chapter: Alginates - A General Overview. In: Pereira L, editor. Alginates - Recent Uses of This Natural Polymer. IntechOpen; 2020. 
173. Wang HD, Li XC, Lee DJ, Chang JS. Potential biomedical applications of marine algae. Bioresour Technol 2017;244:1407-15.

174. Bilal M, Iqbal HMN. Marine seaweed polysaccharides-based engineered cues for the modern biomedical sector. Mar Drugs 2020;18:7.

175. Sezer AD, Cevher E. Fucoidan: A Versatile Biopolymer for Biomedical Applications. In: Zilberman M, editor. Active Implants and Scaffolds for Tissue Regeneration. Berlin: Springer Berlin Heidelberg; 2011. pp. 377-406.

176. Liu L, Heinrich M, Myers S, Dworjanyn SA. Towards a better understanding of medicinal uses of the brown seaweed Sargassum in Traditional Chinese Medicine: a phytochemical and pharmacological review. J Ethnopharmacol 2012;142:591-619.

177. McKim JM, Willoughby JA Sr, Blakemore WR, Weiner ML. Clarifying the confusion between poligeenan, degraded carrageenan, and carrageenan: A review of the chemistry, nomenclature, and in vivo toxicology by the oral route. Crit Rev Food Sci Nutr 2019;59:3054-73.

178. Pal A, Kamthania MC, Kumar A. Bioactive compounds and properties of seaweeds-a review. OALib 2014;01:1-17.

179. Silva TH, Alves A, Ferreira BM, et al. Materials of marine origin: a review on polymers and ceramics of biomedical interest. Int Mater Rev 2013;57:276-306.

180. Pereira L. Biological and therapeutic properties of the seaweed polysaccharides. Int Biol Rev 2018;2:1-50.

181. Pereira H, Barreira L, Figueiredo F, et al. Polyunsaturated Fatty acids of marine macroalgae: potential for nutritional and pharmaceutical applications. Mar Drugs 2012;10:1920-35.

182. Huheihel M, Ishanu V, Tal J, Arad S. Activity of Porphyridium sp. polysaccharide against herpes simplex viruses in vitro and in vivo. $J$ Biochem Biophys Methods 2002;50:189-200.

183. Palumbo MO, Kavan P, Miller WH Jr, et al. Systemic cancer therapy: achievements and challenges that lie ahead. Front Pharmacol 2013;4:57.

184. Muniyan S, Xi L, Datta K, et al. Cardiovascular risks and toxicity - The Achilles heel of androgen deprivation therapy in prostate cancer patients. Biochim Biophys Acta Rev Cancer 2020;1874:188383.

185. Mayer AMS, Rodríguez AD, Taglialatela-Scafati O, Fusetani N. Marine pharmacology in 2012-2013: marine compounds with antibacterial, antidiabetic, antifungal, anti-inflammatory, antiprotozoal, antituberculosis, and antiviral activities; affecting the immune and nervous systems, and other miscellaneous mechanisms of action. Mar Drugs 2017;15:273.

186. Djulbegovic B, Kumar A, Soares HP, et al. Treatment success in cancer: new cancer treatment successes identified in phase 3 randomized controlled trials conducted by the National Cancer Institute-sponsored cooperative oncology groups, 1955 to 2006. Arch Intern Med 2008;168:632-42.

187. Nass SJ, Levit LA, Gostin LO. The Value, Importance, and Oversight of Health Research. In: Nass SJ, Levit LA, Gosti LO, editors. Beyond the HIPAA Privacy Rule: Enhancing Privacy, Improving Health Through Research. Washington, D.C., USA: National Academies Press (US); 2009. Available from: https://www.ncbi.nlm.nih.gov/books/NBK9571/. [Last accessed on 28 Nov 2020]

188. Qi X, Liu G, Qiu L, Lin X, Liu M. Marine bromophenol bis(2,3-dibromo-4,5-dihydroxybenzyl) ether, represses angiogenesis in HUVEC cells and in zebrafish embryos via inhibiting the VEGF signal systems. Biomed Pharmacother 2015;75:58-66.

189. Liu M, Wang G, Xiao L, et al. Bis(2,3-dibromo-4,5-dihydroxybenzyl) ether, a marine algae derived bromophenol, inhibits the growth of Botrytis cinerea and interacts with DNA molecules. Mar Drugs 2014;12:3838-51.

190. Liu M, Zhang W, Wei J, Qiu L, Lin X. Marine bromophenol bis(2,3-dibromo-4,5-dihydroxybenzyl) ether, induces mitochondrial apoptosis in K562 cells and inhibits topoisomerase I in vitro. Toxicol Lett 2012;211:126-34.

191. Hanahan D, Weinberg RA. Hallmarks of cancer: the next generation. Cell 2011;144:646-74.

192. Pádua D, Rocha E, Gargiulo D, Ramos A. Bioactive compounds from brown seaweeds: Phloroglucinol, fucoxanthin and fucoidan as promising therapeutic agents against breast cancer. Phytochem Lett 2015;14:91-8.

193. AbuHammad S, Zihlif M. Gene expression alterations in doxorubicin resistant MCF7 breast cancer cell line. Genomics 2013;101:213-20.

194. Shi Z, Liang Y, Chen Z, et al. Overexpression of Survivin and XIAP in MDR cancer cells unrelated to P-glycoprotein. Oncol Rep 2007; 17:969-76.

195. Tegze B, Szállási Z, Haltrich I, et al. Parallel evolution under chemotherapy pressure in 29 breast cancer cell lines results in dissimilar mechanisms of resistance. PLoS One 2012;7:e30804.

196. Yun CW, Kim HJ, Lee SH. Therapeutic Application of Diverse Marine-derived Natural Products in Cancer Therapy. Anticancer Res 2019;39:5261-84.

197. Machana S, Weerapreeyakul N, Barusrux S. Anticancer effect of the extracts from Polyalthia evecta against human hepatoma cell line (HepG2). Asian Pac J Trop Biomed 2012;2:368-74.

198. In vitro antileishmanial, antibacterial, antifungal and anticancer activity of fucoidan from Undaria pinnatifida. Int J Biosci 2017;11:21927.

199. Reyes ME, Riquelme I, Salvo T, Zanella L, Letelier P, Brebi P. Brown Seaweed Fucoidan in Cancer: Implications in Metastasis and Drug Resistance. Mar Drugs 2020;18:232.

200. Eo HJ, Kwon TH, Park GH, et al. In Vitro Anticancer Activity of Phlorofucofuroeckol A via Upregulation of Activating Transcription Factor 3 against Human Colorectal Cancer Cells. Mar Drugs 2016;14:69.

201. Vizetto-Duarte C, Custódio L, Gangadhar KN, et al. Isololiolide, a carotenoid metabolite isolated from the brown alga Cystoseira tamariscifolia, is cytotoxic and able to induce apoptosis in hepatocarcinoma cells through caspase-3 activation, decreased Bcl-2 levels, increased p53 expression and PARP cleavage. Phytomedicine 2016;23:550-7.

202. Kim RK, Uddin N, Hyun JW, Kim C, Suh Y, Lee SJ. Novel anticancer activity of phloroglucinol against breast cancer stem-like cells. Toxicol Appl Pharmacol 2015;286:143-50.

203. Prasedya ES, Miyake M, Kobayashi D, Hazama A. Carrageenan delays cell cycle progression in human cancer cells in vitro demonstrated by FUCCI imaging. BMC Complement Altern Med 2016;16:270. 
204. Yu Q, Yan J, Wang S, et al. Antiangiogenic effects of GFP08, an agaran-type polysaccharide isolated from Grateloupia filicina. Glycobiology 2012;22:1343-52.

205. Cavas L, Baskin Y, Yurdakoc K, Olgun N. Antiproliferative and newly attributed apoptotic activities from an invasive marine alga: Caulerpa racemosa var. cylindracea. J Exp Mar Bio Ecol 2006;339:111-9.

206. Liu Z, Gao T, Yang Y, et al. Anti-Cancer Activity of Porphyran and Carrageenan from Red Seaweeds. Molecules 2019;24:4286.

207. Catarino MD, Silva AMS, Mateus N, Cardoso SM. Optimization of Phlorotannins Extraction from Fucus vesiculosus and Evaluation of Their Potential to Prevent Metabolic Disorders. Mar Drugs 2019;17:162.

208. Hussain SP, Hofseth LJ, Harris CC. Radical causes of cancer. Nat Rev Cancer 2003;3:276-85.

209. Wijesekara I, Yoon NY, Kim SK. Phlorotannins from Ecklonia cava (Phaeophyceae): biological activities and potential health benefits. Biofactors 2010;36:408-14.

210. Li Y, Wijesekara I, Li Y, Kim S. Phlorotannins as bioactive agents from brown algae. Process Biochem 2011;46:2219-24.

211. Lijun H, Nianjun X, Jiangong S, Xiaojun Y, Chengkui Z. Isolation and pharmacological activities of bromophenols fromRhodomela confervoides. Chin J Ocean Limnol 2005;23:226-9.

212. Xu N, Fan X, Yan X, Tseng CK. Screening marine algae from China for their antitumor activities. J Appl Phycol 2004;16:451-6.

213. Shoemaker RH. The NCI60 human tumour cell line anticancer drug screen. Nat Rev Cancer 2006;6:813-23.

214. Sepantafar M, Maheronnaghsh R, Mohammadi H, et al. Engineered Hydrogels in Cancer Therapy and Diagnosis. Trends Biotechnol 2017;35:1074-87.

215. Topalian SL, Weiner GJ, Pardoll DM. Cancer immunotherapy comes of age. J Clin Oncol 2011;29:4828-36.

216. Reed SG, Orr MT, Fox CB. Key roles of adjuvants in modern vaccines. Nat Med 2013;19:1597-608.

217. Moyer MW. New adjuvants aim to give whooping cough vaccine a boost. Nat Med 2012;18:991.

218. Costa LS, Fidelis GP, Cordeiro SL, et al. Biological activities of sulfated polysaccharides from tropical seaweeds. Biomed Pharmacother 2010;64:21-8.

219. Maruyama H, Tamauchi H, Iizuka M, Nakano T. The role of NK cells in antitumor activity of dietary fucoidan from Undaria pinnatifida sporophylls (Mekabu). Planta Med 2006;72:1415-7.

220. Chen LM, Liu PY, Chen YA, et al. Oligo-Fucoidan prevents IL-6 and CCL2 production and cooperates with p53 to suppress ATM signaling and tumor progression. Sci Rep 2017;7:11864.

221. Pan TJ, Li LX, Zhang JW, et al. Antimetastatic Effect of Fucoidan-Sargassum against Liver Cancer Cell Invadopodia Formation via Targeting Integrin $\alpha \mathrm{V} \beta 3$ and Mediating $\alpha \mathrm{V} \beta 3$ /Src/E2F1 Signaling. J Cancer 2019;10:4777-92.

222. Luo M, Shao B, Nie W, et al. Antitumor and Adjuvant Activity of $\lambda$-carrageenan by Stimulating Immune Response in Cancer Immunotherapy. Sci Rep 2015;5:11062.

223. Song K, Xu L, Zhang W, et al. Laminarin promotes anti-cancer immunity by the maturation of dendritic cells. Oncotarget 2017;8:3855467.

224. Sun J, Sun J, Song B, et al. Fucoidan inhibits CCL22 production through NF-אB pathway in M2 macrophages: a potential therapeutic strategy for cancer. Sci Rep 2016;6:35855.

225. Park HB, Hwang J, Zhang W, et al. Polysaccharide from Codium fragile Induces Anti-Cancer Immunity by Activating Natural Killer Cells. Mar Drugs 2020;18:626.

226. Pawar VK, Singh Y, Sharma K, et al. Improved chemotherapy against breast cancer through immunotherapeutic activity of fucoidan decorated electrostatically assembled nanoparticles bearing doxorubicin. Int J Biol Macromol 2019;122:1100-14.

227. Cunha L, Grenha A. Sulfated Seaweed Polysaccharides as Multifunctional Materials in Drug Delivery Applications. Mar Drugs 2016;14:42.

228. Adachi M, Watanabe S. Evaluation of combined deactivators-supplemented agar medium (CDSAM) for recovery of dermatophytes from patients with tinea pedis. Med Mycol 2007;45:347-9.

229. Yew WW, Tong SCW, Lui KS, Leung SKF, Chau CH, Wang EP. Comparison of MB/BacT system and agar proportion method in drug susceptibility testing of Mycobacterium tuberculosis. Diagn Microbiol Infect Dis 2001;39:229-32.

230. Sathuvan M, Thangam R, Gajendiran M, et al. $\kappa$-Carrageenan: An effective drug carrier to deliver curcumin in cancer cells and to induce apoptosis. Carbohydr Polym 2017;160:184-93.

231. Sezer AD, Cevher E, Hatipoğlu F, Oğurtan Z, Baş AL, Akbuğa J. The use of fucosphere in the treatment of dermal burns in rabbits. Eur J Pharm Biopharm 2008;69:189-98.

232. Lai YH, Chiang CS, Hsu CH, Cheng HW, Chen SY. Development and Characterization of a Fucoidan-Based Drug Delivery System by Using Hydrophilic Anticancer Polysaccharides to Simultaneously Deliver Hydrophobic Anticancer Drugs. Biomolecules 2020;10:970.

233. Thakur SS, Shenoy SK, Suk JS, Hanes JS, Rupenthal ID. Validation of hyaluronic acid-agar-based hydrogels as vitreous humor mimetics for in vitro drug and particle migration evaluations. Eur J Pharm Biopharm 2020;148:118-25.

234. Wu C, Zhao J, Hu F, et al. Design of injectable agar-based composite hydrogel for multi-mode tumor therapy. Carbohydr Polym 2018;180:112-21.

235. Venkatesan J, Anil S, Kim SK, Shim MS. Seaweed Polysaccharide-Based Nanoparticles: Preparation and Applications for Drug Delivery. Polymers (Basel) 2016;8:30.

236. Zhang C, Wang W, Wang C, et al. Cytotoxicity of liver targeted drug-loaded alginate nanoparticles. Sci China Ser B-Chem 2009;52:13827.

237. Zhang C, Wang W, Liu T, et al. Doxorubicin-loaded glycyrrhetinic acid-modified alginate nanoparticles for liver tumor chemotherapy. Biomaterials 2012;33:2187-96. 
238. Roy D, Cambre JN, Sumerlin BS. Future perspectives and recent advances in stimuli-responsive materials. Prog Polym Sci 2010;35:278301.

239. Bouhadir KH, Alsberg E, Mooney DJ. Hydrogels for combination delivery of antineoplastic agents. Biomaterials 2001;22:2625-33.

240. Chemoprotective Agents. Available from: https://chemoth.com/chemoprotective. [Last accessed on 15 Nov 2020]

241. Shin T, Ahn M, Hyun JW, Kim SH, Moon C. Antioxidant marine algae phlorotannins and radioprotection: a review of experimental evidence. Acta Histochem 2014;116:669-74.

242. Park E, Lee NH, Joo HG, Jee Y. Modulation of apoptosis of eckol against ionizing radiation in mice. Biochem Biophys Res Commun 2008;372:792-7.

243. Shibata T, Ishimaru K, Kawaguchi S, Yoshikawa H, Hama Y. Antioxidant activities of phlorotannins isolated from Japanese Laminariaceae. J Appl Phycol 2008;20:705-11.

244. Besednova NN, Zvyagintseva TN, Kuznetsova TA, et al. Marine Algae Metabolites as Promising Therapeutics for the Prevention and Treatment of HIV/AIDS. Metabolites 2019;9:87.

245. Kim AR, Lee MS, Shin TS, et al. Phlorofucofuroeckol A inhibits the LPS-stimulated iNOS and COX-2 expressions in macrophages via inhibition of NF-kB, Akt, and p38 MAPK. Toxicol In Vitro 2011;25:1789-95.

246. Chang MY, Byon SH, Shin HC, et al. Protective effects of the seaweed phlorotannin polyphenolic compound dieckol on gentamicininduced damage in auditory hair cells. Int J Pediatr Otorhinolaryngol 2016;83:31-6.

247. Liu EH, Qi LW, Wu Q, Peng YB, Li P. Anticancer agents derived from natural products. Mini Rev Med Chem 2009;9:1547-55.

248. van Weelden G, Bobiński M, Okła K, van Weelden WJ, Romano A, Pijnenborg JMA. Fucoidan Structure and Activity in Relation to AntiCancer Mechanisms. Mar Drugs 2019;17:32.

249. Kwak JY. Fucoidan as a marine anticancer agent in preclinical development. Mar Drugs 2014;12:851-70.

250. Fletcher H, Biller P, Ross A, Adams J. The seasonal variation of fucoidan within three species of brown macroalgae. Algal Res 2017;22:79-86.

251. Riou D, Colliec-Jouault S, Pinczon Du Sel D, et al. Antitumor and antiproliferative effects of a fucan extracted from Ascophyllum nodosum against a non-small-cell bronchopulmonary carcinoma line. Anticancer Res 1996;16:1213-8.

252. Lin Y, Qi X, Liu H, Xue K, Xu S, Tian Z. The anti-cancer effects of fucoidan: a review of both in vivo and in vitro investigations. Cancer Cell Int 2020;20:154.

253. Tokita Y, Nakajima K, Mochida H, Iha M, Nagamine T. Development of a fucoidan-specific antibody and measurement of fucoidan in serum and urine by sandwich ELISA. Biosci Biotechnol Biochem 2010;74:350-7.

254. Lowenthal RM, Fitton JH. Are seaweed-derived fucoidans possible future anti-cancer agents? J Appl Phycol 2015;27:2075-7.

255. Tsai HL, Tai CJ, Huang CW, Chang FR, Wang JY. Efficacy of Low-Molecular-Weight Fucoidan as a Supplemental Therapy in Metastatic Colorectal Cancer Patients: A Double-Blind Randomized Controlled Trial. Mar Drugs 2017;15:122.

256. Tocaciu S, Oliver LJ, Lowenthal RM, et al. The Effect of Undaria pinnatifida Fucoidan on the Pharmacokinetics of Letrozole and Tamoxifen in Patients With Breast Cancer. Integr Cancer Ther 2018;17:99-105.

257. Ikeguchi M, Yamamoto M, Arai Y, et al. Fucoidan reduces the toxicities of chemotherapy for patients with unresectable advanced or recurrent colorectal cancer. Oncol Lett 2011;2:319-22.

258. Scheuer PJ, Hammann MT, Gravalos DG. US-6011010-A - Cytotoxic and antiviral compound. 1997.

259. Suárez Y, González L, Cuadrado A, Berciano M, Lafarga M, Muñoz A. Kahalalide F, a new marine-derived compound, induces oncosis in human prostate and breast cancer cells. Mol Cancer Ther 2003;2:863-72.

260. Martín-Algarra S, Espinosa E, Rubió J, et al. Phase II study of weekly Kahalalide F in patients with advanced malignant melanoma. Eur J Cancer 2009;45:732-5.

261. Claudio F, Stendardo B. An experimental contribution to the clinical use of an algal phytocolloid (Algasol T331) in oncology. Proceedings of the Fifth International Seaweed Symposium, Halifax, August 25-28, 1965. Elsevier; 1966. pp. 369. 